Article

\title{
Aronia melanocarpa (Michx.) Elliot, Chaenomeles superba Lindl. and Cornus mas L. Leaf Extracts as Natural Preservatives for Pork Meat Products
}

\author{
Magdalena Efenberger-Szmechtyk ${ }^{1, *(D)}$, Ilona Gałązka-Czarnecka ${ }^{2}$, Anna Otlewska ${ }^{1}$, Agata Czyżowska ${ }^{1}$ (D \\ and Agnieszka Nowak ${ }^{1}$ (D)
}

check for updates

Citation: Efenberger-Szmechtyk, M.; Gałązka-Czarnecka, I.; Otlewska, A.; Czyżowska, A.; Nowak, A. Aronia melanocarpa (Michx.) Elliot,

Chaenomeles superba Lindl. and Cornus mas L. Leaf Extracts as Natural Preservatives for Pork Meat Products. Molecules 2021, 26, 3009. https:// doi.org/10.3390/molecules26103009

Academic Editors: Ana Gomes, Lillian Barros and Taofiq Oludemi

Received: 9 April 2021

Accepted: 15 May 2021

Published: 18 May 2021

Publisher's Note: MDPI stays neutral with regard to jurisdictional claims in published maps and institutional affiliations.

Copyright: (c) 2021 by the authors. Licensee MDPI, Basel, Switzerland. This article is an open access article distributed under the terms and conditions of the Creative Commons Attribution (CC BY) license (https:/ / creativecommons.org/licenses/by/ $4.0 /)$.
1 Institute of Fermentation Technology and Microbiology, Lodz University of Technology, Wolczanska 171/173, 90-924 Lodz, Poland; anna.otlewska@p.lodz.pl (A.O.); agata.czyzowska@p.lodz.pl (A.C.); agnieszka.nowak@p.lodz.pl (A.N.)

2 Institute of Food Technology and Analysis, Lodz University of Technology, Stefanowskiego 4/10, 90-924 Lodz, Poland; ilona.galazka-czarnecka@p.lodz.pl

* Correspondence: magdalena.efenberger-szmechtyk@edu.p.lodz.pl

\begin{abstract}
The aim of this study was to investigate the possibility of using Aronia melanocarpa, Chaenomeles superba, and Cornus mas leaf extracts as natural preservatives for pork meat products. Pork sausages were stored in modified atmosphere packaging (MAP) $\left(80 \% \mathrm{~N}_{2}\right.$ and $\left.20 \% \mathrm{CO}_{2}\right)$ at $4{ }^{\circ} \mathrm{C}$ for 29 days. The total psychrotrophic counts (TPC) were determined during the storage period, along with the numbers of Enterobacteriaceae and lactic acid bacteria (LAB). The extracts improved the microbial quality of the meat products but to a lesser extent than sodium nitrate (III). They reduced the amounts of Enterobacteriaceae and LAB. The A. melanocarpa leaf extract showed the strongest preservative effect. The bacterial biodiversity of the meat products was investigated based on high-throughput sequencing of the 16S rRNA gene. Two predominant bacteria phyla were identified, Proteobacteria and Firmucutes, mostly consisting of genera Photobacterium, Brochothrix, and Carnobacterium. The extracts also influenced microbial community in sausages decreasing or increasing bacterial relative abundance. The extracts significantly inhibited lipid oxidation and improved the water-holding capacity of the meat, with $C$. superba extract showing the strongest influence. In addition, $A$. melanocarpa and C. superba improved the redness $\left(\mathrm{a}^{*}\right)$ of the sausages. The results of this study show that $A$. melanocarpa, C. superba, and C. mas leaf extracts can extend the shelf life of meat products stored in MAP at $4{ }^{\circ} \mathrm{C}$.
\end{abstract}

Keywords: Aronia melanocarpa; Chaenomeles superba; Cornus mas; meat; $16 \mathrm{~S}$ rRNA gene sequencing; natural preservatives

\section{Introduction}

Meat is a good environment for the growth of many microorganisms. The following bacteria are commonly found in meat and meat products: Pseudomonas fragi, Pseudomonas fluorescens, Acinetobacter sp., Moraxella sp., Escherichia coli, Staphylococcus aureus, Flavobacterium sp., Micrococcus sp., Bacillus sp., Streptococcus sp., Serratia sp., Carnobacterium sp., Lactobacillus sp., Lactococcus sp., Leuconostoc sp., Brochothrix thermosphacta, Enteroccus sp., Proteus sp., Psychrobacter sp., Alkaliphilus sp., Kluyvera sp. and Clostridium sp. Fungi such as Candida sp., Rhodotorula sp., Cladosporium sp., and Cryptococcus sp. can also occur, but they are not predominant microflora. Meat products can also become contaminated with pathogenic bacteria, such as Listeria monocytogenes, Salmonella sp., Clostridium botulinum, Yersinia enterocolitica, Campylobacter jejuni, and pathogenic strains of E. coli [1-4].

To inhibit the growth of microorganisms and extend the shelf life of meat products, food preservatives are routinely added during meat processing [5,6]. Using food preservatives is regulated by Commission Regulation (EC) No 1333/2008 of the European 
Parliament and of the Council of 16 December 2008 on food additives. Preservatives permitted to be used in meat and meat products include sulfur dioxide-sulfates (IV) (E220-228), potassium nitrate (III) (E249), sodium nitrate (III) (E250), sodium nitrate (V) (E251), potassium nitrate (V) (E252), acetic acid (E260), potassium acetate (E261), sodium acetate (E262), calcium acetate (E263), sorbic acid-sorbates (E200-203), benzoic acid-benzoates (E210-213), p-hydroxybenzoates (E214-219), natamycin (E235), and lactic acid (E270). In cured pork sausages, which were prepared in our studies, nitrates (III) (E249 and E250) are permitted to be used. Nitrates (III), usually in mixtures with salt, have many useful properties. First of all, they inhibit the growth of spoilage and pathogenic bacteria (including spore-forming Clostridium botulinum). They also reduce the oxidation of meat ingredients and improve the organoleptic properties of meat. Finally, they give to meat products their characteristic pink-red color. However, nitrates (III) can be very harmful to human health. Heating processes $\left(\mathrm{t}>130^{\circ} \mathrm{C}\right)$, such as grilling or frying, and near acidic $\mathrm{pH}$ support the reaction of nitrates (III) with amino compounds in meat, leading to the formation of highly carcinogenic nitrosamines $[7,8]$.

There is great interest in finding new and natural methods of meat preservation, which would be safe for human consumption and improve the health benefits of food products. Due to their antioxidant and antibacterial properties, plant extracts rich in polyphenols can effectively inhibit meat spoilage processes and thus offer a promising alternative to chemical preservatives [9-11]. Moreover, polyphenols have well-documented health benefits, such as anti-diabetic, anti-allergic, anti-atherogenic, anti-hypertensive, anti-thrombotic, cardioprotective, osteoprotective, neuroprotective, anti-aging, hepatoprotective, and anticancer effects [12]. Studies have shown that plant extracts containing high amounts of polyphenols effectively inhibit the growth of spoilage and pathogenic microflora in meat, oxidation processes, discoloration, and organoleptic changes [9,11].

In recent years, there has been a growing interest in the application of plant leaf extracts rich in polyphenols to meat and meat products, including olive [13], blackcurrant and sour cherry leaf extracts [14], cork oak [15], bamboo [16], eucalyptus [17], Moringa oleifera and Bidens pilosa leaf extracts [18], and curry and mint [19] leaf extracts. According to the literature, the leaves contain larger amounts of polyphenols than other parts of plants $[20,21]$. Unlike fruits, leaves do not contain simple sugars, which can stimulate the growth of microorganisms. Leaves are usually considered a waste material. When they fall from trees, they may be used to protect plants during the winter or in the production of compost. Due to the exceptional properties, abundance, and low cost of leaves, there is great potential for the use of leaf extracts as natural preservatives in the meat industry.

Apart from polyphenolic extracts, essential oils also seem to be promising natural preservatives for meat and meat products. Šojić et al. [22] documented the use of wild-thyme by-products in ground pork patties. The extracts protected from color degradation, lipid, and protein oxidation as well as reduced microbial counts in meat products. Stojanović-Radić et al. [23] reported that basil and rosemary essential oils exerted antioxidant effect in chicken meat and reduced the amounts of pathogenic bacteria Salmonella Enteritidis.

Our previous studies showed that A. melanocarpa, C. superba, and C. mas leaf extracts are rich sources of bioactive compounds-mainly polyphenols (phenolic acids and flavonols) with strong antioxidant properties. In addition, C. superba extract was found to contain flavones and flavanones, while ellagitannins and iridoids (non-phenolic antioxidant compounds) were identified in the C. mas extracts. The extracts showed antibacterial activity against meat spoilage and pathogenic bacteria [24,25]. We further demonstrated that $A$. melanocarpa, C. superba, and C. mas leaf extracts possess cytotoxic and genotoxic properties toward the human colon adenocarcinoma cell line Caco-2, which may indicate anticancer activity [26]. To our knowledge, there have been no previous studies in which extracts from the leaves of A. melanocarpa, C. superba, and C. mas were applied to meat and meat products. 
The aim of the present study was to investigate the application of A. melanocarpa, C. superba, and C. mas leaf extracts as natural preservatives in pork sausages, as alternatives to nitrates (III). We evaluated the influence of the leaf extracts on the microbial stability, lipid oxidation, drip loss, color parameters, and sensory properties of pork sausages stored at $4{ }^{\circ} \mathrm{C}$ in MAP. We also investigated the effects of the extracts on the microbial diversity of the meat products, which was based on high-throughput sequencing of the 16S rRNA gene.

\section{Results and Discussion}

\subsection{Effect of Leaf Extracts on Microbial Counts in Meat Products}

In our previous studies, we demonstrated that A. melanocarpa, C. superba, and C. mas extracts show antibacterial activity against typical meat spoilage and pathogenic bacteria. The leaf extracts decreased the bacterial growth rate $\left(\mu_{\max }\right)$ and extended the lag phase $\left(t_{\text {Lag }}\right)$, indicating a bacteriostatic effect [24]. In further studies, the leaf extracts showed bactericidal activity and decreased bacteria viability [25]. Therefore, in the current research, we investigated the application of A. melanocarpa, C. superba, and C. mas leaf extracts as natural preservatives in pork meat products. We evaluated if they could be alternatives to nitrates (III), which are commonly used preservatives in meat products that are harmful to human health. The influence of A. melanocarpa, C. superba, and C. mas leaf extracts on the shelf life of pork sausages was investigated during 29 days of refrigerated storage in MAP. We prepared the following variants of sausages: AMS—sausage with A. melanocarpa leaf extract ( $5 \% v / w)$; ChS—sausage with C. superba leaf extract ( $5 \% v / w)$; CMS—sausage with $C$. mas leaf extract $(5 \% v / w)$. We also prepared sausages containing sodium nitrate (III)—NS sample. An SS sample without plant extract and nitrates (III) was a reference sample in this study.

Curing salt containing sodium nitrate (III) had the strongest influence on the microbial stability of the meat products during storage at $4{ }^{\circ} \mathrm{C}$. The greatest increase in the number of bacteria was noted in the SS sample. Generally, the extracts inhibited the growth of microorganisms in the sausages (compared to SS). The preservative effect depended on the type of extract, storage time, and the group of microorganisms (Table 1).

Among the extracts studied, A. melanocarpa had the strongest effect on the microbial parameters of the meat products. (Table 1). The extract had an inhibitory effect on all the studied groups of microorganisms, over the whole storage period, but at varying degrees. A. melanocarpa extract was the most active toward Enterobacteriaceae. Similarly to sodium nitrate (III), the extract significantly reduced Enterobacteriaceae counts up to 15 days of storage compared to the SS sample. After that time, the extract still had antibacterial activity, although the influence was lower. $C$ superba also inhibited Enterobacteriaceae up to 15 days, although to a lesser degree. The C. mas extract showed an inhibitory effect on Enterobacteriaceae at the beginning of storage (up to 8 days).

Regarding lactic acid bacteria (LAB) counts, $A$. melanocarpa inhibited its growth significantly up to 15 days of storage. Interestingly, the $C$. mas extract did not influence the results for $\mathrm{LAB}$ at the beginning of the storage period (up to day 4). However, after 8-15 days of storage, the $C$. mas extract reduced LAB compared to SS. It is worth noting that after 11 and 15 days of storage, LAB counts in AMS and CMS samples were lower than in the NS sample. C. superba inhibited LAB up to 8 days of storage.

The extracts showed weak antibacterial activity toward psychrotrophic bacteria. Only sodium nitrate (III) strongly reduced total psychrotrophic count (TPC). A. melanocarpa and C. mas extracts decreased TPC in a statistically significant manner $(p<0.05)$, but from a practical point of view, it was irrelevant.

Therefore, A. melanocarpa, C. mas, and C. superba leaf extracts showed an inhibitory effect on Enterabacteriaceae and LAB. The extracts improved the microbial quality of meat products up to 15 days of storage. The extracts revealed slightly weaker activity than sodium nitrate (III); however, they sufficiently inhibited the growth of microorganisms and can replace the use of nitrates (III). No significant effect of leaf extracts on TPC can result from differences in bacterial communities, as evidenced further by metagenomics analysis. 
Table 1. Effect of Aronia melanocarpa, Chaenomeles superba and Cornus mas leaf extracts on microbial counts in pork sausages stored in MAP at $4{ }^{\circ} \mathrm{C}$ (mean $\left.\pm \mathrm{SD}\right)$.

\begin{tabular}{|c|c|c|c|c|c|c|c|}
\hline \multirow[b]{2}{*}{ Storage Time (Day) } & \multicolumn{7}{|c|}{ LOG(CFU/g) } \\
\hline & 1 & 4 & 8 & 11 & 15 & 22 & 29 \\
\hline & \multicolumn{7}{|c|}{ TPC } \\
\hline AMS & $2.62 \pm 0.11^{c}$ & $3.79 \pm 0.05^{c}$ & $6.33 \pm 0.08^{b}$ & $6.57 \pm 0.11^{c}$ & $7.14 \pm 0.08^{c}$ & $7.54 \pm 0.04^{b}$ & $7.66 \pm 0.17^{b}$ \\
\hline ChS & $3.89 \pm 0.10^{\mathrm{a}}$ & $4.07 \pm 0.06^{\mathrm{b}}$ & $6.20 \pm 0.08^{b}$ & $7.33 \pm 0.03^{\mathrm{a}}$ & $8.30 \pm 0.04^{\mathrm{a}}$ & $7.89 \pm 0.08^{a}$ & $8.15 \pm 0.11^{a}$ \\
\hline CMS & $3.85 \pm 0.06^{\mathrm{a}}$ & $4.48 \pm 0.02^{\mathrm{a}}$ & $5.82 \pm 0.11^{c}$ & $6.25 \pm 0.06^{\mathrm{d}}$ & $6.90 \pm 0.07^{\mathrm{d}}$ & $7.22 \pm 0.06^{c}$ & $8.13 \pm 0.08^{a}$ \\
\hline NS & $3.33 \pm 0.06^{b}$ & $3.72 \pm 0.04^{c}$ & $4.21 \pm 0.13^{\mathrm{d}}$ & $4.98 \pm 0.27^{\mathrm{e}}$ & $6.39 \pm 0.34^{\mathrm{e}}$ & $6.67 \pm 0.19^{d}$ & $7.49 \pm 0.10^{b}$ \\
\hline \multirow[t]{2}{*}{ SS } & $3.91 \pm 0.08^{\mathrm{a}}$ & $4.46 \pm 0.05^{\mathrm{a}}$ & $6.81 \pm 0.11^{\mathrm{a}}$ & $6.98 \pm 0.06^{\mathrm{b}}$ & $7.50 \pm 0.13^{b}$ & $8.05 \pm 0.14^{\mathrm{a}}$ & $7.93 \pm 0.09^{a}$ \\
\hline & \multicolumn{7}{|c|}{ Enterobacteriaceae } \\
\hline AMS & $1.65 \pm 0.08^{a . b}$ & $1.00 \pm 0.02^{c}$ & $2.62 \pm 0.26^{b}$ & $2.50 \pm 0.18^{\mathrm{e}}$ & $3.65 \pm 0.07^{b}$ & $4.69 \pm 0.12^{b . c}$ & $5.13 \pm 0.02^{c}$ \\
\hline ChS & $1.66 \pm 0.22^{a . b}$ & $1.63 \pm 0.16^{\mathrm{b}}$ & $2.81 \pm 0.09^{b}$ & $3.77 \pm 0.10^{c}$ & $4.57 \pm 0.15^{\mathrm{a}}$ & $4.61 \pm 0.12^{c}$ & $6.23 \pm 0.21^{a}$ \\
\hline CMS & $1.74 \pm 0.06^{\mathrm{a}}$ & $1.70 \pm 0.05^{\mathrm{b}}$ & $2.72 \pm 0.20^{b}$ & $4.18 \pm 0.16^{\mathrm{b}}$ & $4.71 \pm 0.10^{\mathrm{a}}$ & $5.61 \pm 0.10^{\mathrm{a}}$ & $6.24 \pm 0.14^{\mathrm{a}}$ \\
\hline NS & $1.45 \pm 0.21^{\mathrm{b}}$ & $1.70 \pm 0.07^{\mathrm{b}}$ & $1.78 \pm 0.06^{\mathrm{c}}$ & $2.88 \pm 0.05^{\mathrm{d}}$ & $3.29 \pm 0.31^{b}$ & $4.30 \pm 0.18^{\mathrm{d}}$ & $5.30 \pm 0.18^{b . c}$ \\
\hline \multirow[t]{2}{*}{ SS } & $1.65 \pm 0.07^{a . b}$ & $2.32 \pm 0.15^{\mathrm{a}}$ & $3.42 \pm 0.16^{\mathrm{a}}$ & $4.47 \pm 0.21^{\mathrm{a}}$ & $4.64 \pm 0.10^{\mathrm{a}}$ & $4.96 \pm 0.18^{b}$ & $5.41 \pm 0.17^{\mathrm{b}}$ \\
\hline & \multicolumn{7}{|c|}{ LAB } \\
\hline AMS & $1.45 \pm 0.21^{c}$ & $2.00 \pm 0.13^{c}$ & $3.31 \pm 0.18^{b}$ & $3.64 \pm 0.13^{c}$ & $4.89 \pm 0.05^{c}$ & $5.71 \pm 0.08^{c}$ & $6.17 \pm 0.02^{c}$ \\
\hline ChS & $2.00 \pm 0.13^{b}$ & $2.52 \pm 0.20^{b}$ & $2.82 \pm 0.09^{c}$ & $4.86 \pm 0.09^{\mathrm{a}}$ & $5.58 \pm 0.03^{b}$ & $6.19 \pm 0.14^{b}$ & $6.32 \pm 0.01^{b}$ \\
\hline CMS & $2.40 \pm 0.12^{\mathrm{a}}$ & $2.86 \pm 0.08^{\mathrm{a}}$ & $3.34 \pm 0.05^{b}$ & $3.55 \pm 0.20^{c}$ & $3.58 \pm 0.23^{d}$ & $6.45 \pm 0.02^{\mathrm{a}}$ & $6.15 \pm 0.04^{c}$ \\
\hline NS & $1.48 \pm 0.18^{c}$ & $1.93 \pm 0.04^{c}$ & $3.42 \pm 0.06^{b}$ & $4.69 \pm 0.14^{a . b}$ & $5.65 \pm 0.05^{b}$ & $5.18 \pm 0.13^{\mathrm{d}}$ & $6.14 \pm 0.13^{c}$ \\
\hline SS & $2.33 \pm 0.18^{a}$ & $2.75 \pm 0.06^{a . b}$ & $4.17 \pm 0.18^{\mathrm{a}}$ & $4.65 \pm 0.05^{b}$ & $5.94 \pm 0.09^{a}$ & $6.04 \pm 0.07^{b}$ & $6.74 \pm 0.09^{a}$ \\
\hline
\end{tabular}

$\mathrm{a}, \mathrm{b}, \mathrm{c}, \mathrm{d}, \mathrm{e}$ - statistically significant differences between the variants of sausages $(p<0.05)$ : AMS—sausage with Aronia melanocarpa leaf extract $(5 \% v / w)$; ChS—sausage with Chaenomeles superba leaf extract (5\% v/w); CMS—-sausage with Cornus mas leaf extract (5\% v/w); NS—sausage with curing salt containing sodium nitrate (III); SS—control sausage with salt and spices only (without extract and nitrates (III)); TPC—-total psychrotrophic count; LAB-lactic acid bacteria.

Figure 1 presents a Principal Component Analysis (PCA) of the influence of $A$. melanocarpa, C. superba, and C. mas leaf extracts on the population of bacteria (TPC, Enterobacteriaceae, LAB) in the pork sausages. PC1 and PC2 explain $89.58 \%$ of total variance for TPC, $84.97 \%$ for Enterobacteriaceae and $83.34 \%$ for LAB. PCA confirms that sodium nitrate (III) as well as A. melanocarpa, C. superba, and C. mas leaf extracts show antibacterial activity in meat. In Figure 1A, the ChS sample is located close to the SS sample, indicating that the C. superba extract had no effect on TPC, whereas the NS, AMS, and CMS samples are separated from the SS sample, suggesting inhibitory activity. In the case of Enterobacteriaceae and LAB (Figure 1B,C), the samples are located far from the SS sample, which suggests that all the extracts inhibited the growth of these bacteria groups.

Our previous studies had found that $C$. mas extract had the strongest antibacterial activity against bacteria strains typical for meat, followed by C. superba and A. melanocarpa $[24,25]$. However, in the present study, we found that A. melanocarpa increased the shelf life of the meat products the most. This may be associated with the different absorption of bioactive compounds in the extracts in the meat environment. It has been reported that polyphenols can interact with food components such as proteins, carbohydrates, fiber, and fat, which can affect their absorption and also change their bioactivity [27,28].

Saleh et al. [13] investigated the effect of olive leaf extract on the microbial quality of poultry meat. The extract reduced the total mesophilic count (TMC), TPC, total Enterobacteriaceae count, total staphylococcal count, and total mold and yeast counts, compared to the control. The extract had less of an influence on the shelf life of meat at a concentration of $0.25 \%(w / v)$ than at concentrations of 0.5 and $1 \%(w / v)$. Cui et al. [29] showed that Morus alba leaf extract significantly decreased TMC in chilled pork meat during storage compared to the control. Nowak et al. [14] demonstrated that sour cherry and blackcurrant leaf extracts extended the shelf life of vacuum packed pork sausages during 14 days of refrigerated storage. The extracts inhibited bacterial growth, decreasing TMC, TPC, LAB, Pseudomonas sp., B. thermosphacta, and Enterobacteriaceae counts. 

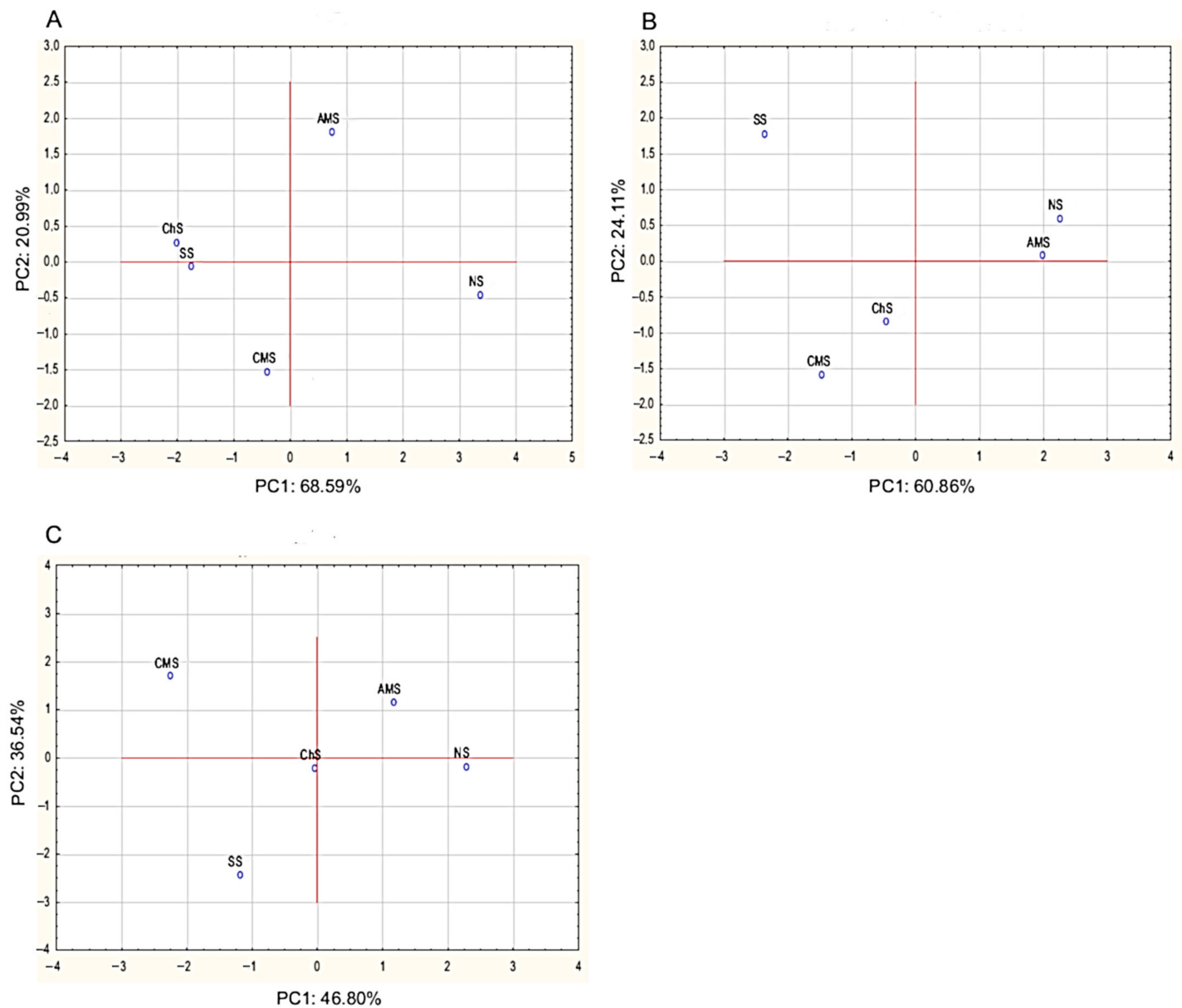

Figure 1. Principal Component Analysis (PCA) showing the effects of Aronia melanocarpa, Chaenomeles superba, and Cornus mas leaf extracts on the microbial quality of pork sausages during 29 days of refrigerated storage in MAP. AMS—sausage with Aronia melanocarpa leaf extract (5\% v/w); ChS—sausage with Chaenomeles superba leaf extract ( $5 \%$ v/w); CMS—sausage with Cornus mas leaf extract ( $5 \% v / w)$; NS—-sausage with curing salt containing sodium nitrate (III); SS-control sausage with salt and spices only (without extract and nitrates (III)); (A)—total psychrotrophic count (TPC); (B)—Enterobacteriaceae; (C) -lactic acid bacteria (LAB).

2.2. Identification of Bacterial Communities in Meat Products by High-Throughput Sequencing of the $16 S$ rRNA Gene

The bacterial communities in the different variants of pork meat products stored in MAP were identified using high-throughput sequencing on an Illumina platform. Samples of the sausages were selected for metagenomic analysis after 1, 8, and 29 days of storage. The results of our studies show that $A$. melanocarpa, C. superba, and C. mas leaf extracts influence microbial community in pork sausages. Figure 2 presents the bacterial phyla identified in the meat products. The predominant phyla in all sausage variants were Firmicutes and Proteobacteria. During refrigerated storage, the relative abundance of Firmicutes increased, whereas the relative abundance of Proteobacteria decreased. At the beginning of the storage period, Proteobacteria constituted $96.61-99.02 \%$ of OTUs (operational taxonomic units). However, by the end of the storage period, they represented $49.32-73.50 \%$ of OTUs, depending on the sausage variant. It is worth noting that the relative abundance of Firmucutes at the beginning of storage was only 0.95-3.09\% of OTUs. However, after 29 days, it reached $26.42-50.64 \%$ of OTUs, depending on the sausage variant. The most significant change was observed in the case of the AMS sample. As well as Firmicutes and Proteobacteria, other bacterial phyla were detected in the meat products, including Acidobaceriota, Actinobacteriota, Bacteroidota, Bdellovibrionota, Campilobacteriota, Chloroflexi, Desulfobacteriota, Gemmatimonadota, Halanaerobiaeota, Planctomycetota, and Verrucomicrobiota. 

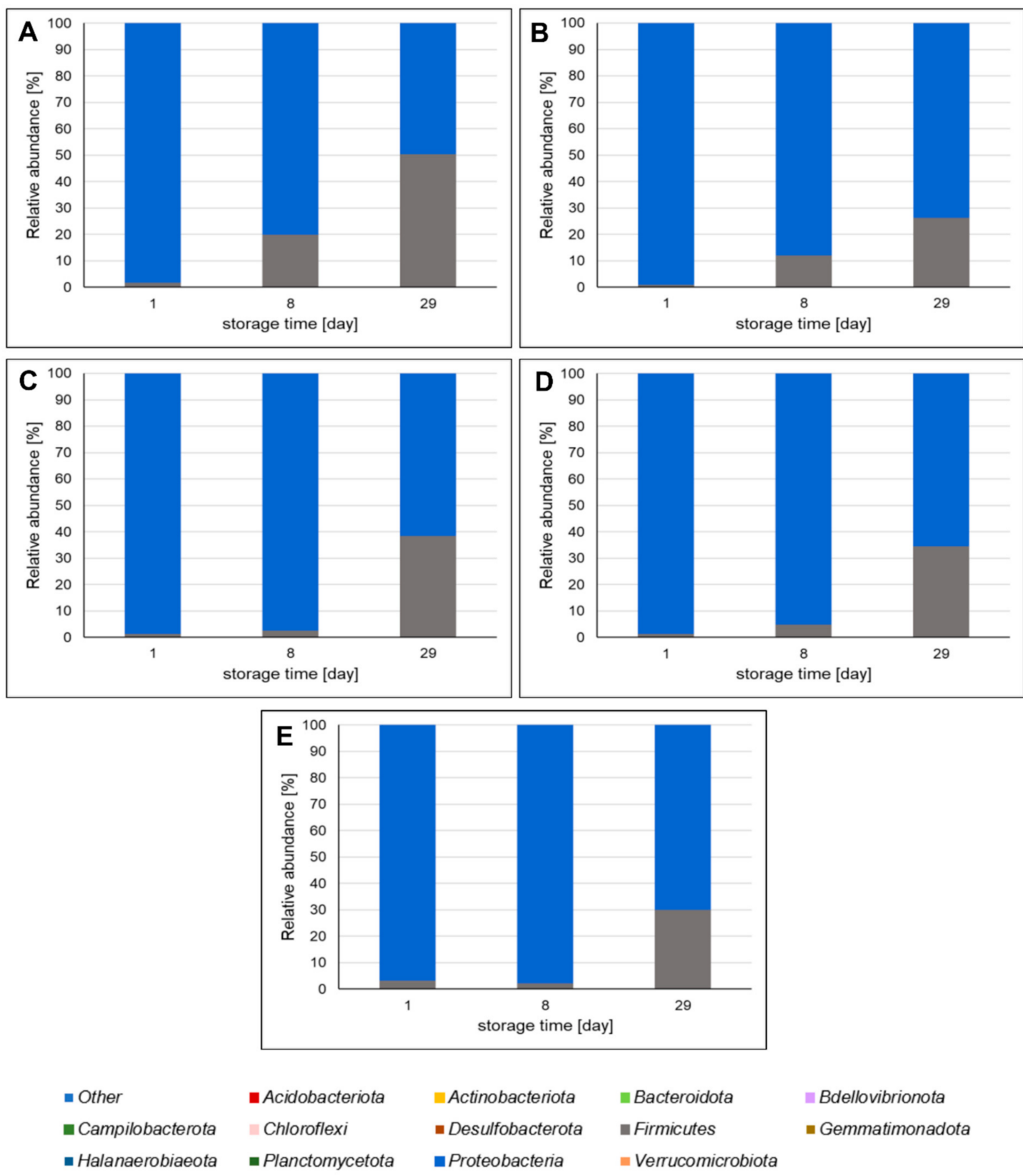

Figure 2. Bacterial phyla identified in pork sausages stored in MAP at $4{ }^{\circ} \mathrm{C}$ based on high-throughput sequencing of the $16 \mathrm{~S}$ rRNA gene. The results are expressed as percentage share of each bacterial phylum in sausages. (A)—sausage with Aronia melanocarpa leaf extract; (B)—sausage with Chaenomeles superba leaf extract; (C)—sausage with Cornus mas leaf extract; (D) - sausage with curing salt containing sodium nitrate (III); (E) — control sausage with salt and spices only (without extract and nitrates (III)).

Figure 3 presents the most abundant genera among Proteobacteria phylum. The predominant genus was Photobacterium sp., which at the start of storage represented 98.19-99.54\% of Proteobacteria OTUs, depending on the sausage variant. During storage, the amount of Photobacterium sp. decreased slightly, reaching $86.08-97.60 \%$ after 29 days. It was also observed that the relative abundance of Psychrobacter sp., Serratia sp., and Vibrio sp. increased during storage. In addition, the influence of extracts on bacteria diversity among Proteobacteria phylum was noticed. The smallest change in bacterial diversity was detected in the case of the SS sample. The relative abundance of Psychrobacter sp. and Serratia sp. was higher in samples containing leaf extracts and sodium nitrate (III), compared to the SS sample. A. melanocarpa had the greatest influence on Psychrobacter sp. Moreover, C. mas and 
C. superba leaf extracts as well as sodium nitrate (III) increased the relative abundance of Vibrio sp. This suggests that both the leaf extracts and nitrates (III) have inhibitory activity against Photobacterium sp. and/or can stimulate the growth of Psychrobacter sp., Serratia sp., and Vibrio sp.
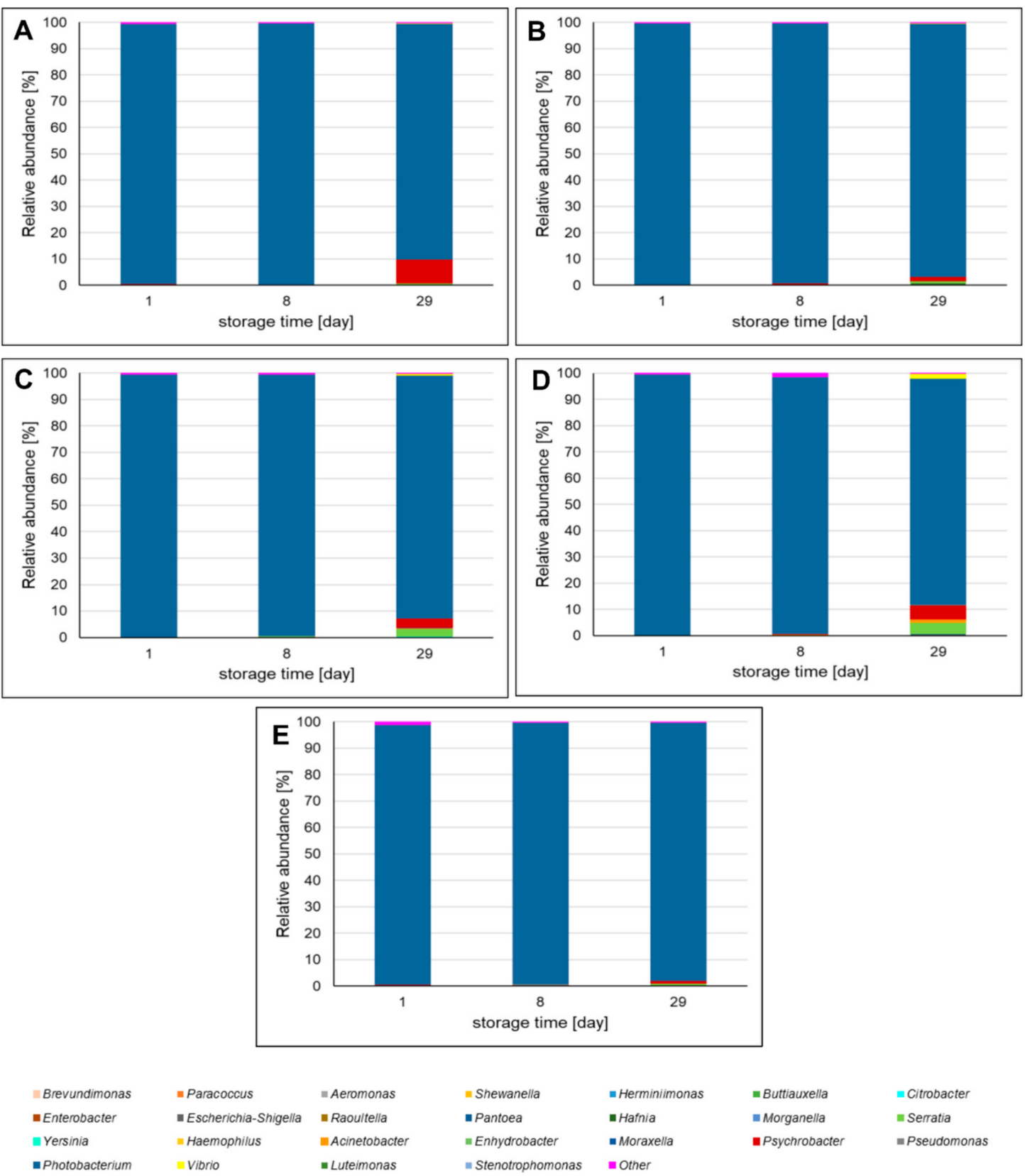

Figure 3. The most abundant genera among Proteobacteria phylum identified in pork sausages stored in MAP at $4{ }^{\circ} \mathrm{C}$ based on high-throughput sequencing of the $16 \mathrm{~S}$ rRNA gene. The results are expressed as percentage share of each bacterial genius making up the total number of identified genera in each sausage sample among Proteobacteria phylum. Bacteria genera with percentage relative abundance $>0.01 \%$ are shown. (A)—sausage with Aronia melanocarpa leaf extract; (B)—sausage with Chaenomeles superba leaf extract; (C)—sausage with Cornus mas leaf extract; (D)—sausage with curing salt containing sodium nitrate (III); (E)— control sausage with salt and spices only (without extract and nitrates (III)).

At the start of storage, the Firmicutes phylum was mainly represented by Carnobacterium sp. (50.30-65.16\% of Firmicutes OTUs) (Figure 4). However, during storage, Brochothrix sp. came to predominate, constituting after 29 days $70.29-94.65 \%$ of Firmicutes OTUs. During storage, the relative abundance of Lactococcus sp., Lactobacillus sp., and 
Staphylococcus sp. also decreased. It was noticed that the extracts influenced the diversity of Firmicutes phylum in pork sausages. In the AMS and ChS samples, and to a lesser degree in the CMS sample, the microbial community profile changed rapidly after 8 days of storage compared to the NS and SS samples. This suggests that leaf extracts inhibit the growth of Carnobaterium sp. and/or favor the growth of Brochothrix sp. The relative abundance of Lactococcus sp., Lactobacillus sp., and Staphylococcus sp. was lower in sausages with plant extracts than in NS and SS samples, which also suggests the inhibitory activity of leaf extracts.
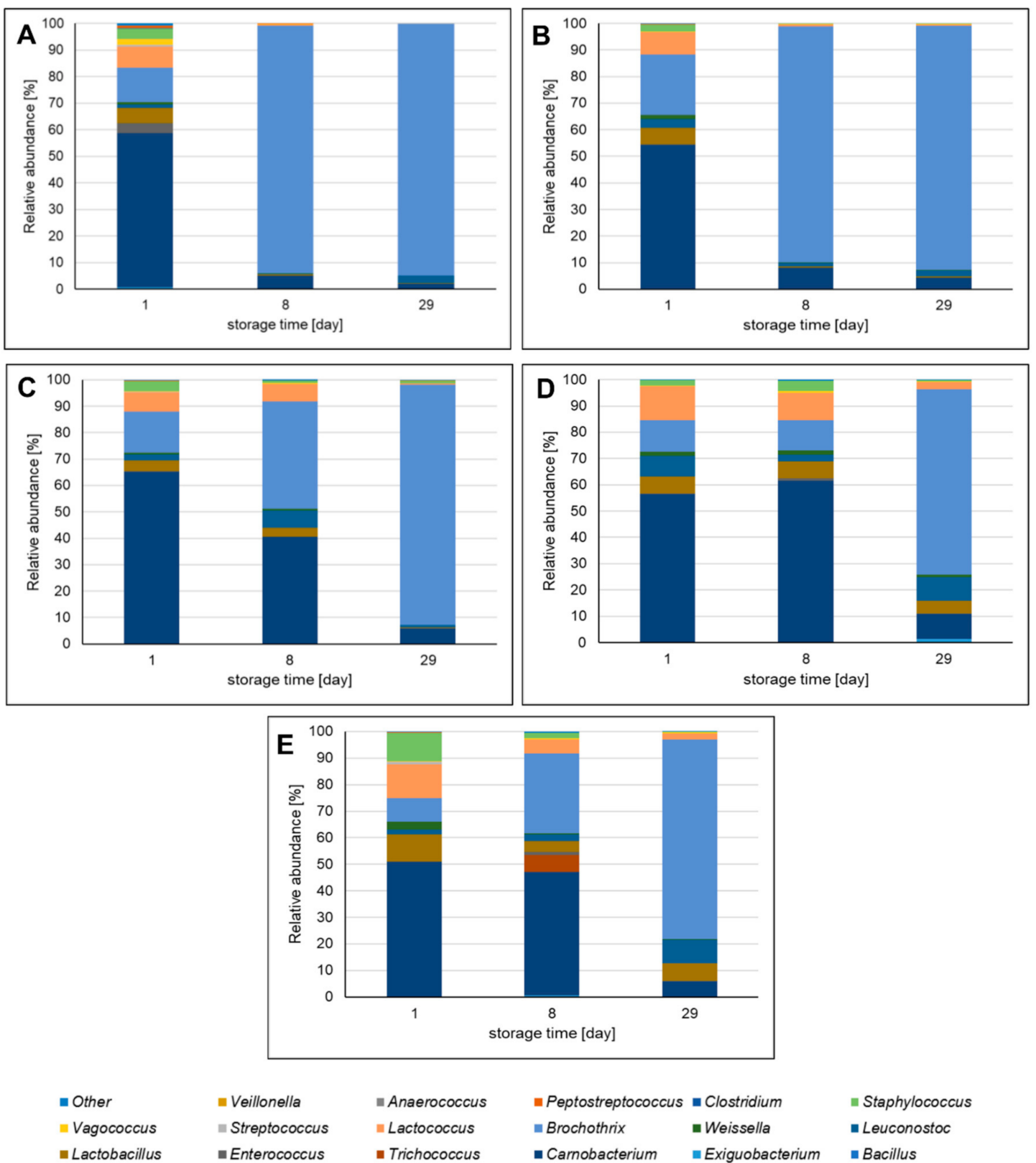

Figure 4. The most abundant genera among Firmicutes phylum identified in pork sausages stored in MAP at $4{ }^{\circ} \mathrm{C}$ based on high-throughput sequencing of the 16S rRNA gene. The results are expressed as the percentage share of each bacterial genius making up the total number of identified genera in each sausage sample among Firmicutes phylum. Bacteria genera with percentage relative abundance $>0.01 \%$ are shown. (A) - sausage with Aronia melanocarpa leaf extract; (B)-sausage with Chaenomeles superba leaf extract; (C)—sausage with Cornus mas leaf extract; (D)—sausage with curing salt containing sodium nitrate (III); (E)—control sausage with salt and spices only (without extract and nitrates (III)). 
Our research showed that depending on the storage time, three bacteria genera generally predominated: Photobacterium, Brochothrix, and Carnobacterium. The high abundance of Photobacterium sp. in the pork sausages was unexpected. According to the literature, these bacteria do not usually constitute one of the predominant microflora in meat, including pork meat [1-4]. However, our results are in agreement with a study by Nieminen et al. [30], which also found that the bacterial communities in pork meat were composed predominantly of Photobacterium sp. and Brochothrix sp., as well as Carnobacterium sp., Lactobacillus sp., Lactococcus sp., and Leuconostoc sp. According to the same research, the relative abundance of Photobacterium sp. decreased during storage, while the relative abundance of Brochothrix sp. increased.

Since they occur mainly in seawater, sediment, or from interactions with marine animals, Photobacterium sp. are associated mainly with spoiled fish and seafood products [31,32]. However, several studies have noted the presence of these bacteria in meat products, including beef, chicken, turkey, and pork meat [30,33,34]. Hilgarth et al. [34] found Photobacterium sp. in 50\% of tested meat samples, in quantities of up to $10^{7} \mathrm{CFU} / \mathrm{g}$. They were isolated from $53 \%$ of the chicken samples, $22 \%$ of the pork meat samples, and $100 \%$ of the beef samples, as well as in $100 \%$ of the salmon samples. The main species of Photobacterium found in meat are Photobacterium phosphoreum, Photobacterium carnosum, and Photobacterium iliopiscarium [33].

Photobacterium sp. are Gram-negative bacteria belonging to the Vibrioneceae family. They are psychrotrophic or psychrophilic, depending on the species and strain. They are facultatively anaerobic bacteria and can occur in food products packed in different atmospheres, including in air, a vacuum, or MAP [33]. Photobacterium sp. are responsible for spoilage processes in meat. They are able to produce biogenic amines from amino acids, mainly histamine, tyramine, cadaverine, putrescine, and agmatine. They also synthesize ethanol, acetate, diacetyl, formate, lactate, and acetoin from pyruvate, which originates from carbohydrates. In the absence of carbohydrates, pyruvate can be obtained from citrate or glycerol, which are the constituents of lipids in meat. Photobacterium sp. can also use fat (triglycerides) as an energy source for growth. The metabolic pathways of Photobacterium sp. are similar in aerobic and anaerobic packaging atmospheres, such as $\mathrm{CO}_{2} / \mathrm{O}_{2}(30 / 70 \%)$ and $\mathrm{CO}_{2} / \mathrm{N}_{2}(30 / 70 \%)$ [35].

Brochothrix sp. and Carnobacterium sp. possess metabolic traits similar to Photobacterium sp. [35,36], which could explain the competition between these three genera observed in our studies. Previously, it was thought that Brochothrix sp. predominated in highoxygen atmospheres, where they are able to use a wider range of substrates than in anaerobic atmospheres [37]. However, recent studies show that the methabolic pathways of Brochothrix sp. may be similar in both atmospheres [36]. In our study, the sausages were packed in anaerobic MAP $\left(80 \% \mathrm{~N}_{2}\right.$ and $\left.20 \% \mathrm{CO}_{2}\right)$ and Brochothrix sp. predominated. Brochothrix thermosphacta are often detected in meat products. Nowak et al. [37] reported the presence of these bacteria in 130 out of 132 meat samples, in quantities of $10^{1}-10^{9} \mathrm{CFU} / \mathrm{g}$ in meat and $10^{2}-10^{8} \mathrm{CFU} / \mathrm{g}$ in meat products.

Photobacterium sp. need a complex medium with a high content of $\mathrm{NaCl}$ to grow [32]. In our studies, we used a standard medium (PCA), and these bacteria were not detected. High-throughput sequencing of $16 S$ rRNA gene revealed that Photobacterium sp. was one of the predominant microflora in the pork meat sausages. Therefore, in future work, a culturing procedure for these bacteria will be established. Although Photobacterium sp. are not included in microbiological analysis of meat, studies show that they are one of the main groups of bacteria responsible for spoilage processes. Therefore, we recommend testing for Photobacterium sp. and Brochothrix sp. in standard microbiological analyses of meat.

\subsection{Effect of Leaf Extracts on TBARS}

Over 29 days of storage in MAP at $4{ }^{\circ} \mathrm{C}$ for 29 days, the MDA level increased in all sausage variants (Figure 5). The A. melanocarpa, C. superba, and C. mas leaf extracts significantly inhibited lipid oxidation. The highest level of MDA was observed in the 
case of the SS sample. The C. superba extract showed the strongest influence on lipid oxidation, followed by the C. mas and A. melanocarpa extracts. The MDA concentration in the sausages containing leaf extracts (AMS, ChS, and CMS) was even lower than in the NS sample, indicating stronger antioxidant properties compared to sodium nitrate (III). During refrigerated storage, the greatest increase in MDA level was detected in the SS sample (by $0.98 \mathrm{mg}_{\mathrm{MDA}} / \mathrm{kg}$ ) followed by NS (by $\left.0.89_{\mathrm{MDA}} \mathrm{mg} / \mathrm{kg}\right)$, AMS $(0.85 \mathrm{mg} \mathrm{MDA} / \mathrm{kg}), \mathrm{CMS}$ $\left(0.78 \mathrm{mg}_{\mathrm{MDA}} / \mathrm{kg}\right.$ ), and ChS (by $0.69 \mathrm{mg} \mathrm{MDA} / \mathrm{kg}$ ). The effect of A. melanocarpa, C. superba, and $C$. mas leaf extracts on lipid oxidation is associated with the total phenolic content in the extracts and their antioxidant capacity, which had been determined in our previous study [24].

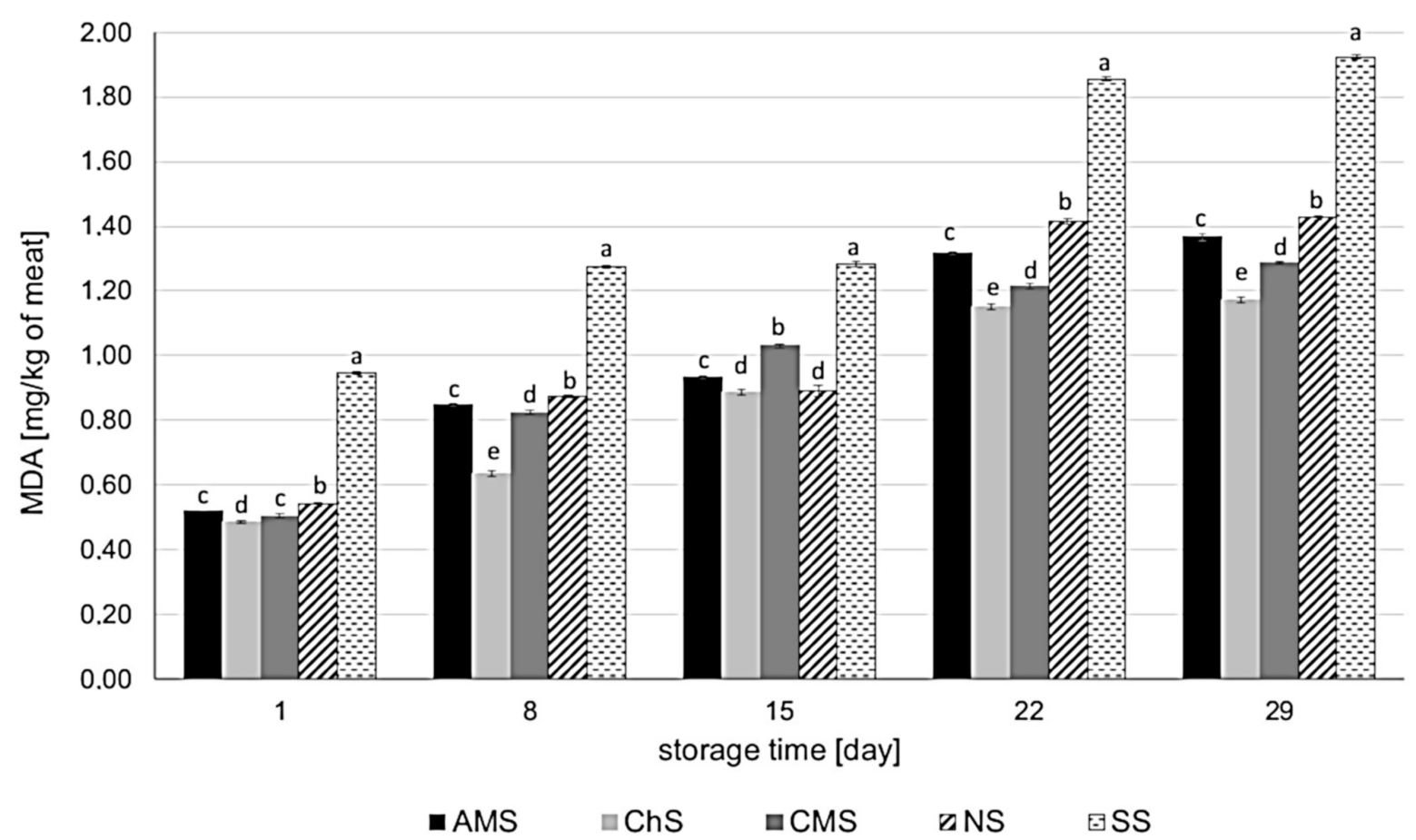

Figure 5. Effect of Aronia melanocarpa, Chaenomeles superba, and Cornus mas leaf extracts on lipid oxidation in pork sausages stored in MAP at $4{ }^{\circ} \mathrm{C}$. The results are expressed as mean $\pm \mathrm{SD}$. a, b, c, d, e-statistically significant differences between the variants of sausages $(p<0.05)$; AMS—sausage with Aronia melanocarpa leaf extract $(5 \% v / w)$; ChS—sausage with Chaenomeles superba leaf extract ( $5 \% v / w)$; CMS—sausage with Cornus mas leaf extract ( $5 \% v / w)$; NS—sausage with curing salt containing sodium nitrate (III); SS—control sausage with salt and spices only (without extract or nitrates (III).

Lipid oxidation is one of the most important parameters determining the quality and shelf life of meat. It is responsible for off-flavors, unacceptable taste, discoloration, loss of nutritional value, the formation of toxic compounds, drip loss, and other alterations that can influence the perception and acceptance of meat by consumers [38]. It is extremely important to add antioxidant substances to meat, due to the fact that sodium chloride can reveal prooxidant properties and stimulate lipid oxidation. There are three possible mechanisms for the pro-oxidant activity of sodium chloride: (1) the disruption of cell membrane integrity, facilitating the access of oxidizing agents to lipid substrates; (2) the liberation of iron ions from molecules containing iron; (3) inhibiting the activity of antioxidant enzymes (e.g., catalase, glutathione peroxidase, superoxide dismutase) [39]. Other chloride salts, especially potassium chloride, can substitute sodium chloride and reduce its prooxidant effect $[40,41]$. However, due to their antioxidant, antibacterial activity, and many health benefits, natural plant extracts rich in polyphenols seem a more interesting alternative $[9,11]$.

The antioxidant properties of plant extracts in meat and meat products are well documented in the literature. Plant extracts can effectively inhibit oxidative changes in 
meat ingredients, suppressing spoilage processes [9,11]. In a study by Biswas et al. [19], curry and mint leaf extracts reduced the MDA concentration in raw ground pork meat during 12 days of refrigerated storage. The curry leaf extract was more effective than both the mint leaf extract and sodium nitrate (III). Saleh et al. [13] reported that poultry meat treated with olive leaf extracts decreased TBARS values compared to the control, especially after 9,12 , and 15 days of storage. After 6 days, the control samples had a rancid flavor, whereas the samples treated with the extract had a normal flavor until the end of the storage period (15 days). According to Nowak et al. [14], sour cherry and blackcurrant water leaf extracts had an inhibitory effect on MDA generation in vacuum-packed pork sausages during 28 days of storage at $4{ }^{\circ} \mathrm{C}$. The sausages were heat treated, cooked, and smoked, as in our study. The antioxidative efficiency was as follows: curing salt $>$ blackcurrant leaf extract $>$ sour cherry leaf extract $>$ salt. Lavado et al. [15] showed that cork oak leaf extracts obtained using different solvents (water, ethanol, water: ethanol $(1: 1 \mathrm{v} / \mathrm{v})$, and water: ethanol $(3: 7 v / v))$ significantly inhibited lipid oxidation in cooked chicken breasts during 10 days of storage. Their antioxidant effect was similar to that of the chemical preservative butylated hydroxytoluene (BHT) at a concentration of $2 \%(v / w)$. No major differences between the types of solvents were observed. As in the studies by Nowak et al. [14] and Lavado et al. [15], we used water extracts and the sausages were heat treated. It is important to note that after thermal treatment of meat products, the extracts remained active and inhibited lipid oxidation.

\subsection{Effect of Leaf Extracts on Drip Loss}

Water-holding capacity is one of the most important quality characteristics of fresh meat. It influences the drip loss, technological quality, appearance, nutritional value, and sensory properties of meat products. During storage, the water-holding capacity of meat decreases and drip loss increases. This means that meat gradually loses its nutritional properties. As mentioned above, polyphenols can bind some substances in meat, such as proteins, carbohydrates, fiber, and fat $[27,28]$, which can help prevent the loss of these substances during storage. Previous studies have only considered the dietary supplementation of animal feed with plant extracts [16,42]. Shen et al. [16] demonstrated that the drip loss from chicken breast meat after $24 \mathrm{~h}$ postmortem decreased when the animals were fed a diet supplemented with bamboo leaf extract. Ao and Kim [42] report that supplementation of feed with grape seed extract decreased the drip loss from duck meat on days 3 and 5 .

In the present research, we found that the studied plant extracts significantly improved the water-holding capacity of pork sausages during 29 days of refrigerated storage $\left(4^{\circ} \mathrm{C}\right)$ in MAP (Figure 6). The extracts showed an even stronger influence on drip loss than sodium nitrate (III). During storage, the drip loss of the variants of pork sausages studied was as follows: SS > NS > AMS CMS > ChS. After 29 days of storage, the drip loss from the sausages increased by $2.64 \mathrm{~mL} / 100 \mathrm{~g}(\mathrm{NS}), 2.44 \mathrm{~mL} / 100 \mathrm{~g}$ (SS), $1.31 \mathrm{~mL} / 100 \mathrm{~g}$ (AMS), $1.29 \mathrm{~mL} / 100 \mathrm{~g}(\mathrm{CMS})$, and $1.00 \mathrm{~mL} / 100 \mathrm{~g}(\mathrm{ChS})$, compared to day 1 . After 29 days, a significant increase in drip loss was observed in the case of the NS sample, whereas the samples with extracts still revealed strong protective ability. Water-holding capacity was associated with total phenolic content. The C. superba extract contained the highest amount of phenolic compounds, followed by the C. mas and A. melanocarpa extracts [24]. 


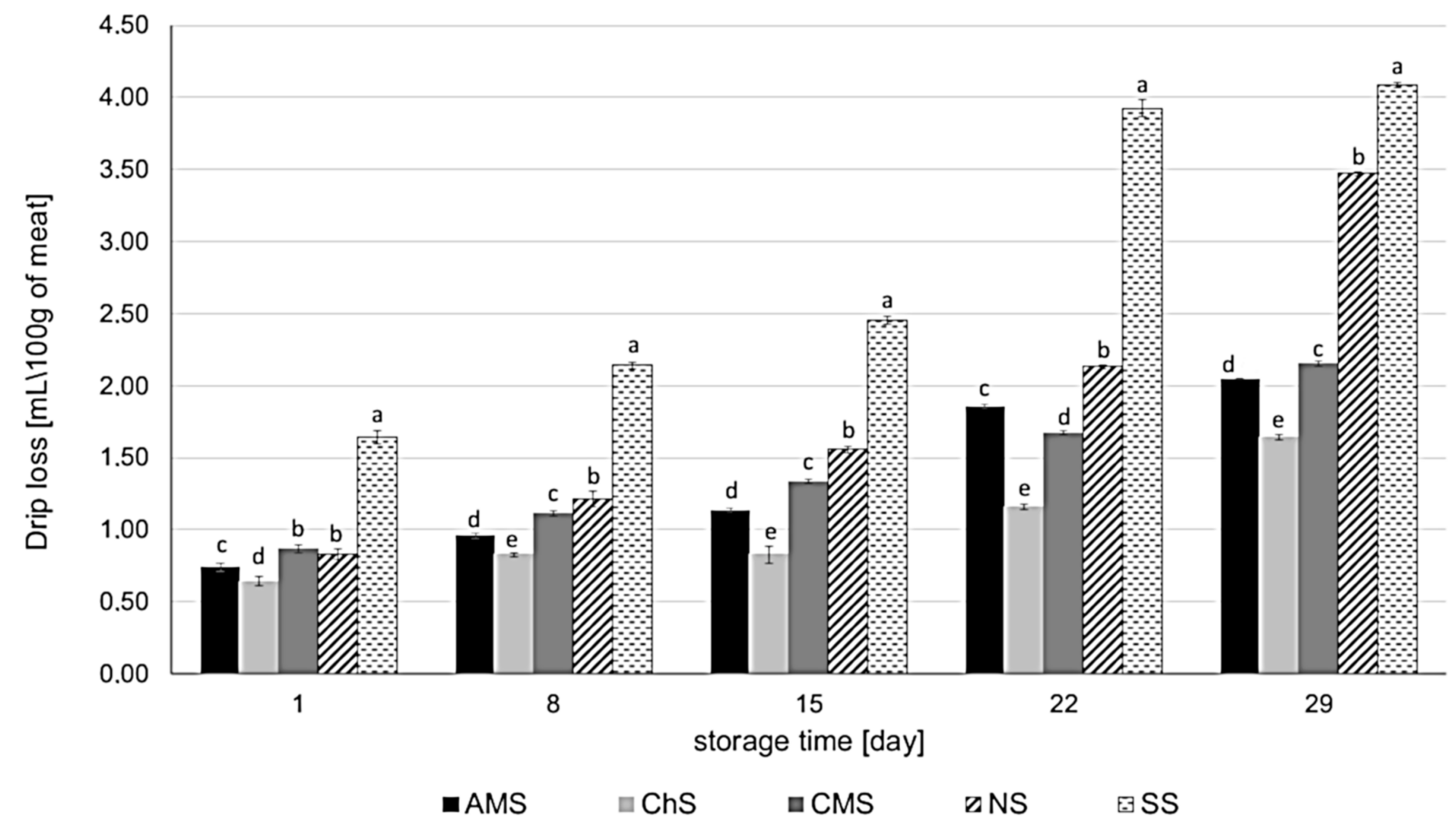

Figure 6. Effect of Aronia melanocarpa, Chaenomeles superba, and Cornus mas leaf extracts on drip loss in pork sausages stored in MAP at $4{ }^{\circ} \mathrm{C}$. The results are expressed as mean \pm SD. a, b, c, d, e-statistically significant differences between the variants of sausages $(p<0.05)$; AMS—sausage with Aronia melanocarpa leaf extract $(5 \% v / w)$; ChS—sausage with Chaenomeles superba leaf extract $(5 \% v / w)$; CMS—-sausage with Cornus mas leaf extract (5\% $v / w)$; NS—sausage with curing salt containing sodium nitrate (III); SS—control sausage with salt and spices only (without extract and nitrates (III)).

\subsection{Effect of Leaf Extracts on Color Parameters}

Table 2 shows the color parameters of the pork sausages containing A. melanocarpa, C. superba, and C. mas leaf extracts during refrigerated storage in MAP. The lightness was generally stable in all the sausage variants during 29 days of storage. The most important color parameter of meat is redness $\left(a^{*}\right)$, which is a characteristic associated with meat products. The highest $\mathrm{a}^{*}$ values were detected for the NS sample. However, the extracts significantly improved the redness of the sausages compared to the SS sample over 29 days of storage. The greatest influence was observed in the case of the AMS sample, followed by $\mathrm{ChS}$ and CMS. This was confirmed by the total color difference, calculated in comparison to the NS sample $\left(\Delta \mathrm{E}_{\mathrm{NS}}\right)$. After 8-22 days of storage, the $\Delta \mathrm{E}_{\mathrm{NS}}$ of the AMS sample was the lowest. We also observed that the redness of the AMS, ChS, CMS, and NS samples increased significantly after 8 days and remained stable during the rest of the storage period. The yellowness of the AMS, ChS, NS, and SS samples did not change significantly during storage. In the case of the AMS sample, a significant decrease in $b^{*}$ values was observed over the whole period of storage.

Ramírez-Rojo et al. [43] reported that mesquite leaf extracts affected the color parameters of pork patties. Initially, the a* values were lower than in the control sample (by $27.8 \%$ ), and the $b^{*}$ values were higher (by $42.1 \%$ ) However, after 10 days of storage, the patties treated with extracts displayed the highest redness and the highest yellowness compared to the control. In a study by Nowak et al. [14], sour cherry and blackcurrant leaf extract were not found to exert a strong influence on the color changes in vacuum-packed pork sausages. Only the blackcurrant leaf extract slightly improved the redness of the meat products compared to the control. Tran et al. [44] report that guava leaf extracts improved the redness of pork sausages, which was comparable to a sample with BHT. However, after 14 days, higher concentrations of the extract showed a prooxidant effect on meat 
color, which could be detrimental. According to Zhang et al. [45], cauliflower leaf extract increased $a^{*}$ values and decreased $L^{*}$ values in pork patties compared to the control.

Table 2. Effect of Aronia melanocarpa, Chaenomeles superba, and Cornus mas leaf extracts on color parameters (Lightness $\mathrm{L}^{*}$, redness $\mathrm{a}^{*}$, yellowness $\mathrm{b}^{*}$ ) of pork sausages stored in MAP at $4{ }^{\circ} \mathrm{C}($ mean $\pm \mathrm{SD})$.

\begin{tabular}{|c|c|c|c|c|c|}
\hline Storage Time [Day] & 1 & 8 & 15 & 22 & 29 \\
\hline \multicolumn{6}{|c|}{ Lightness $\mathrm{L}^{*}$} \\
\hline AMS & $63.90 \pm 0.52^{b, c ~ A ~}$ & $60.50 \pm 0.26^{c B}$ & $63.24 \pm 0.45^{\mathrm{a}, \mathrm{b} \mathrm{A}}$ & $63.18 \pm 0.27^{\mathrm{a} \mathrm{A}}$ & $64.14 \pm 0.44^{\mathrm{a} \mathrm{A}}$ \\
\hline ChS & $63.45 \pm 0.13^{c \mathrm{~A}, \mathrm{~B}, \mathrm{C}}$ & $62.10 \pm 0.35^{\mathrm{b} \mathrm{B}, \mathrm{C}}$ & $63.98 \pm 0.30^{\mathrm{b} \mathrm{A}}$ & $62.06 \pm 0.37^{\mathrm{bC}}$ & $63.78 \pm 0.33^{\mathrm{a}, \mathrm{b} A B}$ \\
\hline CMS & $65.02 \pm 0.93^{\mathrm{a} \mathrm{A}}$ & $62.70 \pm 0.46^{\mathrm{b} \mathrm{A}, \mathrm{B}, \mathrm{C}}$ & $60.69 \pm 0.36^{\mathrm{b} \mathrm{B}, \mathrm{C}}$ & $59.78 \pm 0.25^{\mathrm{cC}}$ & $63.55 \pm 0.33^{a, b ~ A, B}$ \\
\hline NS & $64.63 \pm 0.29^{\mathrm{a}, \mathrm{b} \mathrm{A}}$ & $61.13 \pm 0.42^{\mathrm{cA}}$ & $62.58 \pm 0.26^{\mathrm{a}, \mathrm{b} \mathrm{B}}$ & $63.15 \pm 0.49^{\mathrm{a} \mathrm{A}}$ & $63.25 \pm 0.51^{\mathrm{b} \mathrm{A}}$ \\
\hline SS & $64.85 \pm 0.51^{\mathrm{a}, \mathrm{b} \mathrm{A}} \mathrm{A} \mathrm{B}$ & $65.47 \pm 0.44^{\mathrm{a} \mathrm{A}}$ & $64.50 \pm 0.33^{\text {a A,B }}$ & $62.93 \pm 0.26^{\mathrm{aC}}$ & $63.66 \pm 0.07^{\mathrm{a}, \mathrm{b} B, \mathrm{C}}$ \\
\hline \multicolumn{6}{|c|}{ Redness $a^{*}$} \\
\hline AMS & $4.81 \pm 0.23^{\mathrm{cB}}$ & $8.14 \pm 0.24^{\mathrm{b} \mathrm{A}}$ & $8.15 \pm 0.09 \mathrm{~b} \mathrm{~A}$ & $8.08 \pm 0.08^{b A}$ & $8.09 \pm 0.14^{\mathrm{b} \mathrm{A}}$ \\
\hline ChS & $5.93 \pm 0.42^{\mathrm{b} \mathrm{B}}$ & $7.41 \pm 0.18^{\mathrm{cA}}$ & $8.12 \pm 0.06^{\mathrm{b} \mathrm{A}}$ & $8.06 \pm 0.13^{\mathrm{b} \mathrm{A}}$ & $7.29 \pm 0.18^{c \mathrm{~A}}$ \\
\hline CMS & $6.14 \pm 0.30^{\mathrm{a}, \mathrm{b} B}$ & $7.70 \pm 0.17$ c A & $7.63 \pm 0.10^{\mathrm{c} \mathrm{A}}$ & $7.12 \pm 0.05^{c ~ A, B}$ & $7.58 \pm 0.05^{c \mathrm{~A}}$ \\
\hline NS & $6.60 \pm 0.20$ a $\mathrm{B}$ & $11.01 \pm 0.24 \mathrm{a} \mathrm{A}^{2}$ & $9.91 \pm 0.13^{\text {a A }}$ & $9.08 \pm 0.13^{\text {a A,B }}$ & $9.98 \pm 0.21$ a A \\
\hline SS & $4.55 \pm 0.28^{\mathrm{cC}}$ & $5.52 \pm 0.19 \mathrm{~d} \mathrm{~B}$ & $5.69 \pm 0.03^{\mathrm{d} \mathrm{B}}$ & $6.59 \pm 0.13^{\mathrm{d} A}$ & $6.57 \pm 0.39 \mathrm{~d} \mathrm{~A}$ \\
\hline \multicolumn{6}{|c|}{ Yellowness $b^{*}$} \\
\hline AMS & $13.93 \pm 0.19^{\text {a A }}$ & $13.57 \pm 0.28^{\text {a A,B }}$ & $13.94 \pm 0.07$ a A & $13.00 \pm 0.03^{\mathrm{b} \mathrm{B}}$ & $11.77 \pm 0.10^{\mathrm{d} C}$ \\
\hline ChS & $12.14 \pm 0.11^{\mathrm{cC}}$ & $12.69 \pm 0.03^{\mathrm{b} \mathrm{A}, \mathrm{B}}$ & $12.52 \pm 0.05^{\mathrm{c} \mathrm{A}, \mathrm{B}}$ & $12.36 \pm 0.02^{\mathrm{d} B, C}$ & $12.73 \pm 0.01 \mathrm{~b} \mathrm{~A}$ \\
\hline CMS & $12.07 \pm 0.30^{\mathrm{c} \mathrm{A}}$ & $11.22 \pm 0.02$ c B & $12.23 \pm 0.14^{\mathrm{d} \mathrm{A}}$ & $12.55 \pm 0.05^{\mathrm{cA}}$ & $12.26 \pm 0.10^{\mathrm{c} \mathrm{A}}$ \\
\hline NS & $13.00 \pm 0.11^{\mathrm{b} \mathrm{A}, \mathrm{B}}$ & $12.49 \pm 0.03^{\mathrm{b} \mathrm{B}}$ & $13.81 \pm 0.06^{\mathrm{a} \mathrm{A}}$ & $13.03 \pm 0.05^{\mathrm{b} \mathrm{A}, \mathrm{B}}$ & $13.45 \pm 0.30^{\text {a A }}$ \\
\hline SS & $13.28 \pm 0.18^{\mathrm{b} \mathrm{A}}$ & $13.93 \pm 0.58^{\text {a A }}$ & $13.44 \pm 0.06^{\mathrm{b} \mathrm{A}}$ & $13.52 \pm 0.14^{\mathrm{a} \mathrm{A}}$ & $13.36 \pm 0.01^{\mathrm{a} \mathrm{A}}$ \\
\hline \multicolumn{6}{|c|}{$\Delta \mathrm{E}_{\mathrm{NS}}$} \\
\hline AMS & $2.21 \pm 0.13^{\text {a B }}$ & $3.14 \pm 0.35^{\mathrm{cA}}$ & $1.91 \pm 0.27 \mathrm{~d} \mathrm{~B}$ & $1.02 \pm 0.11 \mathrm{dC}$ & $2.71 \pm 0.20^{\mathrm{b} \mathrm{A}}$ \\
\hline ChS & $1.66 \pm 0.16^{\mathrm{bC}}$ & $3.74 \pm 0.27 \mathrm{~b}, \mathrm{cA}$ & $2.63 \pm 0.18^{\mathrm{cB}}$ & $1.67 \pm 0.11^{\mathrm{c} C}$ & $2.84 \pm 0.24$ b B \\
\hline CMS & $1.44 \pm 0.16^{\mathrm{b} \mathrm{D}}$ & $3.89 \pm 0.30^{\mathrm{b} \mathrm{A}}$ & $3.36 \pm 0.18^{\text {b B }}$ & $3.93 \pm 0.20 \mathrm{a} \mathrm{A}$ & $2.71 \pm 0.06^{\mathrm{bC}}$ \\
\hline SS & $2.14 \pm 0.28^{a D}$ & $7.16 \pm 0.45^{\mathrm{a} \mathrm{A}}$ & $4.65 \pm 0.16^{\mathrm{a} \mathrm{B}}$ & $2.56 \pm 0.15^{b D}$ & $3.44 \pm 0.39 \mathrm{a} \mathrm{C}$ \\
\hline
\end{tabular}

a, b, c, d-statistically significant differences between the sausage variants (in columns) ( $p<0.05)$; A,B,C,D-statistically significant differences during storage (in rows) $(p<0.05)$; AMS—sausage with Aronia melanocarpa leaf extract $(5 \% v / w)$; ChS—sausage with Chaenomeles superba leaf extract ( $5 \% v / w)$; CMS - sausage with Cornus mas leaf extract $(5 \% v / w)$; NS—sausage with curing salt containing sodium nitrate (III); SS-control sausage with salt and spices only (without extract and nitrates (III)); $\Delta \mathrm{E}_{\mathrm{NS}}$ - total color difference in comparison with the NS sample.

\subsection{Sensory Evaluation of Meat Products}

Table 3 shows the sensory properties of the pork sausages stored in MAP at $4{ }^{\circ} \mathrm{C}$. Generally, the extracts did not have a negative impact on the sensory properties of the meat products up to 15 days. The sensory parameters were stable during 8 days of storage. After 15 days, a slight change in odor was observed in the AMS, ChS CMS, and SS samples. The leaf extracts, especially $A$. melanocarpa and C. superba, which were red in color, improved the color of the sausages, which was between the SS and NS samples. No negative effect was detected in terms of taste. The texture of the sausages with $A$. melanocarpa extract was similar to that of the NS sample. However, the C. mas extract had a negative influence on texture. After 22 days, the texture of the CMS samples was uneven, and green traces were observed. The green traces could be due to the release of the extract, which had yellow-green color, or to the activity of microorganisms. This negative change was not observed earlier in the storage period.

According to the literature, meat products enriched with plant extracts containing polyphenols are generally acceptable to consumers, and the extracts do not have a negative impact on their sensory characteristics. In a study by Nowak et al. [14], cherry and blackcurrant leaf extracts were not found to have a negative impact of on the sensory properties of pork sausages, which remained acceptable throughout 14 days of storage. Cui et al. [29] report that Morus alba leaf extract extended the shelf life of pork meat, based on sensory analysis. In contrast to polyphenolic extracts, essential oils can reduce organoleptic acceptability in terms of taste and odor [46]. 
Table 3. Effect of Aronia melanocarpa, Chaenomeles superba, and Cornus mas leaf extracts on the sensory properties of pork sausages stored in MAP at $4{ }^{\circ} \mathrm{C}$.

\begin{tabular}{|c|c|c|c|c|c|c|c|c|c|c|}
\hline Storage Time [Day] & 1 & 8 & 15 & 22 & 29 & 1 & 8 & 15 & 22 & 29 \\
\hline Sausage variant & \multicolumn{5}{|c|}{ Color (1-5) } & \multicolumn{5}{|c|}{ Taste (1-5) } \\
\hline AMS & 4.5 & 4.5 & 4.5 & 4 & 4 & 5 & 5 & n.t. & n.t. & n.t. \\
\hline ChS & 4.5 & 4.5 & 4.5 & 4 & 4 & 5 & 5 & n.t. & n.t. & n.t. \\
\hline CMS & 4 & 4 & 4 & 3.5 & 3.5 & 5 & 5 & n.t. & n.t. & n.t. \\
\hline NS & 5 & 5 & 5 & 4 & 4.5 & 5 & 5 & n.t. & n.t. & n.t. \\
\hline SS & 3 & 3 & 3 & 2.5 & 2 & 5 & 5 & n.t. & n.t. & n.t. \\
\hline Sausage variant & \multicolumn{5}{|c|}{ Odor (1-5) } & \multicolumn{5}{|c|}{ Texture (1-5) } \\
\hline AMS & 5 & 5 & 4.5 & 4 & 4 & 5 & 5 & 5 & 5 & 4.5 \\
\hline ChS & 5 & 5 & 4.5 & 3.5 & 3 & 5 & 5 & 5 & 4.5 & 4 \\
\hline CMS & 5 & 5 & 4.5 & 3.5 & 3 & 5 & 5 & 5 & 3 & 3 \\
\hline NS & 5 & 5 & 5 & 4 & 4 & 5 & 5 & 5 & 5 & 4.5 \\
\hline SS & 5 & 5 & 4 & 3 & 2.5 & 5 & 5 & 5 & 4 & 4 \\
\hline
\end{tabular}

n.t.-not tested; AMS—sausage with Aronia melanocarpa leaf extract (5\% v/w); ChS—sausage with Chaenomeles superba leaf extract (5\% $v / w)$; CMS—-sausage with Cornus mas leaf extract ( $5 \% v / w)$; NS—sausage with curing salt containing sodium nitrate (III); SS—control sausage with salt and spices only (without extract and nitrates (III).

\section{Materials and Methods}

\subsection{Research Material}

The research material consisted of Aronia melanocarpa, Chaenomeles superba, and Cornus mas water leaf extracts. The material was exactly the same as in our previous studies, with the same phenolic content. The total phenolic contents of each extract determined using the Folin-Ciocalteu method were as follows: $861.6 \mu \mathrm{g} / \mathrm{mL}$ (A. melanocarpa); $3110.6 \mu \mathrm{g} / \mathrm{mL}$ (C. superba); $1867.7 \mu \mathrm{g} / \mathrm{mL}$ (C. mas) [24].

\subsection{Preparation of Sausages}

Three classes of pork meat with different fat contents were used to prepare sausages: class 1 (lean, up to 15\% fat), class 2 a (medium fat, 16-20\%), and class $2 b$ (fat, $21-45 \%$ ). The sausages were manufactured at $4{ }^{\circ} \mathrm{C}$. The meat was cut into small cubes and mixed in the following proportions: $10 \%$ lean; $60 \%$ medium fat; $30 \%$ fat. Water, $\mathrm{NaCl}$, spices (pepper and garlic), curing salt, and plant extracts were mixed thoroughly into the meat, according to the proportions shown in Table 4. The following variants of sausages were prepared: AMS—sausages with the addition of A. melanocarpa leaf extract; ChS—sausages with the addition of $C$. superba leaf extract; CMS — sausages with the addition of $C$. mas leaf extract; NS - sausages with the addition of a curing mixture containing sodium nitrate (III); SS-control sausages without extract. The meat samples were stored and cured at $4 \pm 2{ }^{\circ} \mathrm{C}$ for $24 \mathrm{~h}$; then, they were minced using a PM-70 Mincer (MAINCA, Granollers, Spain). The minced meat was stuffed into natural casings using an EC-12 filling machine (MAINCA, Granollers, Spain). Next, the sausages were transported to the Marczak meat processing plant (Dobrzelow, Poland. They were cooked in a steam smokehouse at a temperature of $72{ }^{\circ} \mathrm{C}$ inside the sausage and then smoked using traditional alder and beech wood smoke. After thermal processing, the sausages were cooled, packed in a modified atmosphere $(80 \%$ $\mathrm{N}_{2}$ and $20 \% \mathrm{CO}_{2}$ ), and stored at $4{ }^{\circ} \mathrm{C}$ for 29 days. 
Table 4. Content of additives in the sausage variants.

\begin{tabular}{|c|c|c|c|c|c|c|}
\hline \multirow{2}{*}{ Sausage Variant } & Water & Plant Extract & $\mathrm{NaCl}$ & Curing Salt Containing Sodium Nitrate (III) & Pepper & Garlic \\
\hline & \multicolumn{2}{|c|}{$\mathrm{mL} / 100 \mathrm{~g}$ of Meat } & \multicolumn{4}{|c|}{$\mathrm{mg} / 100 \mathrm{~g}$ of Meat } \\
\hline AMS & 20 & 5 & 1.8 & - & 0.2 & 0.4 \\
\hline ChS & 20 & 5 & 1.8 & - & 0.2 & 0.4 \\
\hline CMS & 20 & 5 & 1.8 & - & 0.2 & 0.4 \\
\hline NS & 20 & & - & 1.8 & 0.2 & 0.4 \\
\hline SS & 20 & - & 1.8 & - & 0.2 & 0.4 \\
\hline
\end{tabular}

AMS—sausage with Aronia melanocarpa leaf extract; ChS—sausage with Chaenomeles superba leaf extract; CMS—sausage with Cornus mas leaf extract; NS—sausage with curing salt containing sodium nitrate (III); SS—control sausage with salt and spices only (without extract and nitrates (III))

\subsection{Microbiological Counts}

Microbiological analysis of the sausages was performed after 1, 4, 8, 11, 15, 22, and 29 days of refrigerated storage at $4{ }^{\circ} \mathrm{C}$. The samples were prepared according to ISO 68872-2017. The total psychrotrophic count (TPC) was determined on Plate Count Agar (PCA) (Merck, Darmstadt, Germany) following incubation at $6{ }^{\circ} \mathrm{C}$ for 6 days. The lactic acid bacteria (LAB) were counted on Man Rogosa Sharpe Agar (MRS) (Merck, Darmstadt, Germany) following incubation for $72 \mathrm{~h}$ at $30^{\circ} \mathrm{C}$. The quantity of Enterobacteriaceae was determined on Violet Red Bile Dextrose Agar (VRBD) (Merck, Darmstadt, Germany) following incubation at $30^{\circ} \mathrm{C}$ for $24 \mathrm{~h}$. The lowest detection limit of the applied enumeration techniques is $10 \mathrm{CFU} / \mathrm{g}$.

\subsection{DNA Extraction, PCR Amplification, and Sequencing}

The total DNA was extracted directly from the meat $(0.5 \mathrm{~g})$ using a DNeasy PowerFood Microbial Kit (Qiagen), according to the manufacturer's instructions. DNA concentrations were assessed using a Qubit 2.0 Fluorometer (Invitrogen/Life Technologies, Carlsbad, CA, USA).

For amplification of the V3-V4 region of the 16S rRNA gene, the universal primer pair 341F/785R was used. PCR reactions were carried out using the Q5 Hot Start High Fidelity $2 \times$ Master Mix (New England BioLabs Inc., Ipswich, MA, USA) under thermal conditions: initial denaturation $98{ }^{\circ} \mathrm{C}$ for $30 \mathrm{~s}$, followed by 25 cycles of denaturation $98^{\circ} \mathrm{C}$ for $10 \mathrm{~s}$, annealing at $55^{\circ} \mathrm{C}$ for $30 \mathrm{~s}$, extension $72{ }^{\circ} \mathrm{C}$ for $30 \mathrm{~s}$, and final extension for $2 \mathrm{~min}$ at $72{ }^{\circ} \mathrm{C}$.

DNA libraries were constructed using a Nextera Index Kit (ThermoFisher Scientific, USA) following the protocol provided by manufacturer. High-throughput sequencing of $16 \mathrm{~S}$ rRNA libraries were performed on the Illumina MiSeq platform by Genomed S.A. (Warsaw, Poland).

Preliminary data analysis was carried out using a MiSeq apparatus with MiSeq Reporter (MSR) v 2.6 software (Illumina, Inc., San Diego, CA, USA). Each sample was demultiplexed, and fastq files containing raw reads were generated. Bioinformatic analysis to classify the readings was carried out using QIIME 2 software based on the SILVA v 138 database. The procedure consisted of the following steps: removal of adapter sequences; evaluation of the quality of the readings and removal of low-quality sequences connecting paired sequences; clustering based on the selected database of reference sequences and removal of sequence chimeras [47-49]. The sequences were clustered using the uclust algorithm [50]. Operational Taxonomic Units (OTUs) were assigned to taxa to the selected database of reference sequences.

\subsection{Determination of TBARS}

Lipid stability was evaluated according to the method proposed by Targladis et al. [51], with some modifications. All sausage variants were analyzed after 1, 8, 15, 22, and 29 days of refrigerated storage. The experiments were conducted in triplicate. The sausage samples were minced using a Zelmer 686 meat mincer (Zelmer S.A., Rzeszow, Poland). A $5 \mathrm{~g}$ sample with $75 \mathrm{~mL}$ of distilled water and $7 \mathrm{~mL}$ of $3 \mathrm{M} \mathrm{HCl}$ was transferred to a distillation 
system. About $20 \mathrm{~mL}$ of the distillate was collected and $3 \mathrm{~mL}$ of $0.02 \mathrm{M}$ thiobarbituric acid (TBA) was added. The reaction mixture was heated in a boiling bath for $35 \mathrm{~min}$ and cooled to room temperature. The absorbance was measured at $530 \mathrm{~nm}$ against distilled water using a T60V spectrophotometer (PG Instruments, Leicestershire, United Kingdom). The amounts of thiobarbituric acid reactive substances (TBARS) were determined according to the standard curve $\left(\mathrm{R}^{2}=0.98\right)$ and expressed as mg malondialdehyde (MDA) $/ \mathrm{kg}$ of meat.

\subsection{Drip Loss}

Drip loss was determined using the filter paper press method described by Grau and Hamm [52], with some modifications. The sausage samples were minced. A total of $0.5 \mathrm{~g}$ of each sample was placed on the paper filter between two cover glasses under a pressure of $200 \mathrm{~g}$ for $10 \mathrm{~min}$. Using a planimeter, the difference (RZ) between the wet area on the filter paper $(\mathrm{T})$ and the area of the pressed meat $(\mathrm{M})$ was determined. The amount of water that leaked from the meat sample was calculated according to the calibration curve $\left(\mathrm{R}^{2}=0.99\right)$.

\subsection{Instrumental Color Measurement}

Color parameters were measured using a CR-400 Chroma Meter (Minolta Ltd., Milton Keynes, UK). The meat samples were minced and measurements were performed directly on the surface of the meat. The color parameters were determined using the CIEL ${ }^{*} \mathrm{a}^{*}$ system. The results were expressed as lightness $\left(\mathrm{L}^{*}\right)$, redness $\left(\mathrm{a}^{*}\right)$ and yellowness $\left(\mathrm{b}^{*}\right)$. The color difference $\left(\Delta \mathrm{E}^{*}\right)$ was calculated as follows:

$$
\Delta \mathrm{E}^{2}=\sqrt{\left.\left(\Delta \mathrm{a}^{*}\right)^{2}+\left(\Delta \mathrm{b}^{*}\right)^{2}+\left(\Delta \mathrm{L}^{*}\right)^{2}\right)} .
$$

\subsection{Sensory Analysis}

A trained panel of 10 judges evaluated the sensory properties of the pork sausages at selected points during refrigerated storage. The samples were assessed in terms of taste, color, odor, and texture. Each attribute was scored on a 5-point descriptive scale, where 5 is excellent and 1 is entirely unacceptable.

\subsection{Statistical and Chemometric Analysis}

Mean values and standard deviations were calculated using Microsoft Excel 2013 software. The Tukey Honestly Significant Difference (HSD) test was performed using R 3.4.0 software (R Core Team, Vienna, Austria) $(p<0.05)$. Principal Component Analysis (PCA) was performed using Statistica 13 software (StatSoft, Poland, Kraków).

\section{Conclusions}

In this study, A. melanocarpa, C. superba, and C. mas leaf extracts were added to pork sausages at a concentration of $5 \%(v / w)$, corresponding to a phenolic content of $43.08 \mathrm{mg} / \mathrm{kg}$ of meat for A. melanocarpa, $155.53 \mathrm{mg} / \mathrm{kg}$ of meat for C. superba, and $93.38 \mathrm{mg} / \mathrm{kg}$ of meat for $C$. mas. The extracts improved the microbial quality of meat products during refrigerated storage in MAP but to a lesser extent than sodium nitrate (III). The extracts decreased Enterobacteriaceae and LAB counts with A. melanocarpa showing the greatest influence. Two bacterial phyla predominated in pork sausages, Proteobacteria and Firmicutes, especially the genera Photobacterium sp., Brochothrix sp., and Carnobacterium sp. Therefore, we recommend testing for Brochothrix sp. and Photobaterium sp. in routine microbiological analysis of meat and meat products. The leaf extracts also influenced microbial community of meat products decreasing or increasing bacterial relative abundance (OTUs). The leaf extracts inhibited lipid oxidation and improved the water-holding capacity of the meat (C. superba $>$ C. mas $>$ A. melanocarpa). The extracts (especially A. melanocarpa and C. superba) increased the redness of the sausages, improving the visual attributes of the meat products. The addition of leaf extracts to the meat products did not have a negative effect on their sensory properties up to 15 days of storage. 
Author Contributions: Conceptualization, M.E.-S. and A.N.; methodology, M.E.-S., A.O., I.G.-C.; investigation, M.E.-S., A.O., I.G.-C.; writing—original draft preparation, M.E.-S.; writing-review and editing, A.N., A.C.; supervision, A.N.; All authors have read and agreed to the published version of the manuscript.

Funding: This research received no external funding.

Institutional Review Board Statement: Not applicable.

Informed Consent Statement: Not applicable.

Data Availability Statement: Data is contained within the article.

Conflicts of Interest: The authors declare no conflict of interest.

Sample Availability: Samples of the compounds are not available from the authors.

\section{References}

1. Tian, X.; Wu, W.; Yu, Q.; Hou, M.; Gao, F.; Li, X.; Dai, R. Bacterial diversity analysis of pork longissimus lumborum following long term ohmic cooking and water bath cooking by amplicon sequencing of 16S rRNA gene. Meat Sci. 2017, 123, 97-104. [CrossRef]

2. Peruzy, M.; Murru, N.; Yu, Z.; Kerkhof, P.-J.; Neola, B.; Joossens, M.; Proroga, Y.; Houf, K. Assessment of microbial communities on freshly killed wild boar meat by MALDI-TOF MS and 16S rRNA amplicon sequencing. Int. J. Food Microbiol. 2019, 301, 51-60. [CrossRef] [PubMed]

3. Cauchie, E.; Delhalle, L.; Taminiau, B.; Tahiri, A.; Korsak, N.; Burteau, S.; Fall, P.A.; Farnir, F.; Baré, G.; Daube, G. Assessment of Spoilage Bacterial Communities in Food Wrap and Modified Atmospheres-Packed Minced Pork Meat Samples by $16 \mathrm{~S}$ rDNA Metagenetic Analysis. Front. Microbiol. 2020, 10, 3074. [CrossRef] [PubMed]

4. Ryu, S.; Shin, M.; Cho, S.; Hwang, I.; Kim, Y.; Oh, S. Molecular Characterization of Microbial and Fungal Communities on Dry-Aged Beef of Hanwoo Using Metagenomic Analysis. Foods 2020, 9, 1571. [CrossRef] [PubMed]

5. Nair, B. Final Report on the Safety Assessment of Benzyl Alcohol, Benzoic Acid, and Sodium Benzoate. Int. J. Toxicol. 2001, 20, 23-50. [CrossRef] [PubMed]

6. Silva, M.M.; Lidon, F. Food preservatives-An overview on applications and side effects. Emir. J. Food Agric. 2016, 28, 366-373. [CrossRef]

7. Alahakoon, A.U.; Jayasena, D.D.; Ramachandra, S.; Jo, C. Alternatives to nitrite in processed meat: Up to date. Trends Food Sci. Technol. 2015, 45, 37-49. [CrossRef]

8. Cantwell, M.; Elliott, C. Nitrates, Nitrites and Nitrosamines from Processed Meat Intake and ColorectalCancer Risk. J. Clin. Nutr. Diet. 2017, 03, 27-30. [CrossRef]

9. Papuc, C.; Goran, G.V.; Predescu, C.N.; Nicorescu, V.; Stefan, G. Plant Polyphenols as Antioxidant and Antibacterial Agents for Shelf-Life Extension of Meat and Meat Products: Classification, Structures, Sources, and Action Mechanisms. Compr. Rev. Food Sci. Food Saf. 2017, 16, 1243-1268. [CrossRef]

10. Munekata, P.E.S.; Rocchetti, G.; Pateiro, M.; Lucini, L.; Domínguez, R.; Lorenzo, J.M. Addition of plant extracts to meat and meat products to extend shelf-life and health-promoting attributes: An overview. Curr. Opin. Food Sci. 2020, 31, 81-87. [CrossRef]

11. Efenberger-Szmechtyk, M.; Nowak, A.; Czyzowska, A. Plant extracts rich in polyphenols: Antibacterial agents and natural preservatives for meat and meat products. Crit. Rev. Food Sci. Nutr. 2021, 61, 149-178. [CrossRef]

12. Gorzynik-Debicka, M.; Przychodzen, P.; Cappello, F.; Kuban-Jankowska, A.; Gammazza, A.M.; Knap, N.; Wozniak, M.; GorskaPonikowska, M. Potential Health Benefits of Olive Oil and Plant Polyphenols. Int. J. Mol. Sci. 2018, 19, 686. [CrossRef] [PubMed]

13. Saleh, E.; Morshdy, A.E.; El-Manakhly, E.; Al-Rashed, S.F.; Hetta, H.; Jeandet, P.; Yahia, R.; El-Saber Batiha, G.; Ali, E. Effects of olive leaf extracts as natural preservative on retailed poultry meat quality. Foods 2020, 9, 1017. [CrossRef] [PubMed]

14. Nowak, A.; Czyzowska, A.; Efenberger, M.; Krala, L. Polyphenolic extracts of cherry (Prunus cerasus L.) and blackcurrant (Ribes nigrum L.) leaves as natural preservatives in meat products. Food Microbiol. 2016, 59, 142-149. [CrossRef]

15. Lavado, G.; Ladero, L.; Cava, R. Cork oak (Quercus suber L.) leaf extracts potential use as natural antioxidants in cooked meat. Ind. Crops Prod. 2021, 160, 113086. [CrossRef]

16. Shen, M.; Zhang, L.; Chen, Y.; Zhang, Y.; Han, H.; Niu, Y.; He, J.; Cheng, Y.; Wang, T. Effects of bamboo leaf extract on growth performance, meat quality, and meat oxidative stability in broiler chickens. Poult. Sci. 2019, 98, 6787-6796. [CrossRef]

17. Li, W.; Zhang, X.; He, Z.; Chen, Y.; Li, Z.; Meng, T.; Li, Y.; Cao, Y. In vitro and in vivo antioxidant activity of eucalyptus leaf polyphenols extract and its effect on chicken meat quality and cecum microbiota. Food Res. Int. 2020, 136, 109302. [CrossRef]

18. Falowo, A.B.; Muchenje, V.; Hugo, A.; Aiyegoro, O.A.; Fayemi, P.O. Antioxidant activities of Moringa oleifera L. and Bidens pilosa L. leaf extracts and their effects on oxidative stability of ground raw beef during refrigeration storage. CyTA-J. Food 2016, 15, 249-256. [CrossRef]

19. Biswas, A.; Chatli, M.; Sahoo, J. Antioxidant potential of curry (Murraya koenigii L.) and mint (Mentha spicata) leaf extracts and their effect on colour and oxidative stability of raw ground pork meat during refrigeration storage. Food Chem. 2012, 133, 467-472. [CrossRef] 
20. Teleszko, M.; Wojdyło, A. Comparison of phenolic compounds and antioxidant potential between selected edible fruits and their leaves. J. Funct. Foods 2015, 14, 736-746. [CrossRef]

21. Vagiri, M.; Ekholm, A.; Andersson, S.C.; Johansson, E.; Rumpunen, K. An optimized method for analysis of phenolic com-pounds in buds, leaves, and fruits of black currant (Ribes nigrum L.). J. Agric. Food Chem. 2012, 60, 10501-10510. [CrossRef] [PubMed]

22. Stojanović-Radić, Z.; Pejčić, M.; Joković, N.; Jokanović, M.; Ivić, M.; Šojić, B.; Škaljac, S.; Stojanović, P.; Mihajilov-Krstev, T. Inhibition of Salmonella Enteritidis growth and storage stability in chicken meat treated with basil and rosemary essential oils alone or in combination. Food Control 2018, 90, 332-343. [CrossRef]

23. Šojić, B.; Tomović, V.; Kocić-Tanackov, S.; Kovačević, D.B.; Putnik, P.; Mrkonjić, Ž.; Đurović, S.; Jokanović, M.; Ivića, M.; Škaljac, S.; et al. Supercritical extracts of wild thyme (Thymus serpyllum L.) by-product as natural antioxidants in ground pork patties. LWT 2020, 130, 109661. [CrossRef]

24. Efenberger-Szmechtyk, M.; Nowak, A.; Czyżowska, A.; Kucharska, A.Z.; Fecka, I. Composition and Antibacterial Activity of Aronia melanocarpa (Michx.) Elliot, Cornus mas L. and Chaenomeles superba Lindl. Leaf Extracts. Molecules 2020, 25, 2011. [CrossRef] [PubMed]

25. Efenberger-Szmechtyk, M.; Nowak, A.; Czyżowska, A.; Śniadowska, M.; Otlewska, A.; Żyżelewicz, D. Antibacterial mechanisms of Aronia melanocarpa (Michx.), Chaenomeles superba Lindl. and Cornus mas L. leaf extracts. Food Chem. 2021, 350, 129218. [CrossRef] [PubMed]

26. Efenberger-Szmechtyk, M.; Nowak, A.; Nowak, A. Cytotoxic and DNA-damaging effects of Aronia melanocarpa, Cornus mas, and Chaenomeles superba leaf extracts on the human colon adenocarcinoma cell line Caco-2. Antioxidants 2020, 9, 1030. [CrossRef]

27. D'Archivio, M.; Filesi, C.; Varì, R.; Scazzocchio, B.; Masella, R. Bioavailability of the Polyphenols: Status and Controversies. Int. J. Mol. Sci. 2010, 11, 1321-1342. [CrossRef] [PubMed]

28. Jakobek, L. Interactions of polyphenols with carbohydrates, lipids and proteins. Food Chem. 2015, 175, 556-567. [CrossRef]

29. Cui, H.; Dong, Y.; Lu, T.; Zou, X.; Wang, M.; Yang, X.; Zhou, H. Effect of ethanolic extract from Morus alba L. leaves on the quality and sensory aspects of chilled pork under retail conditions. Meat Sci. 2021, 172, 108368. [CrossRef]

30. Nieminen, T.T.; Dalgaard, P.; Björkroth, J. Volatile organic compounds and Photobacterium phosphoreum associated with spoilage of modified-atmosphere-packaged raw pork. Int. J. Food Microbiol. 2016, 218, 86-95. [CrossRef]

31. Emborg, J.; Laursen, B.; Rathjen, T.; Dalgaard, P. Microbial spoilage and formation of biogenic amines in fresh and thawed modified atmosphere-packed salmon (Salmo salar) at 2oC. J. Appl. Microbiol. 2002, 92, 790-799. [CrossRef]

32. Urbanczyk, H.; Ast, J.C.; Dunlap, P.V. Phylogeny, genomics, and symbiosis ofPhotobacterium. FEMS Microbiol. Rev. 2011, 35, 324-342. [CrossRef]

33. Fuertes-Perez, S.; Hauschild, P.; Hilgarth, M.; Vogel, R.F. Biodiversity of Photobacterium spp. Isolated From Meats. Front. Microbiol. 2019, 10, 2399. [CrossRef] [PubMed]

34. Hilgarth, M.; Fuertes-Pèrez, S.; Ehrmann, M.; Vogel, R.F. An adapted isolation procedure reveals Photobacterium spp. as common spoilers on modified atmosphere packaged meats. Lett. Appl. Microbiol. 2018, 66, 262-267. [CrossRef]

35. Höll, L.; Hilgarth, M.; Geissler, A.J.; Behr, J.; Vogel, R.F. Prediction of in situ metabolism of photobacteria in modified atmos-phere packaged poultry meat using metatranscriptomic data. Microbiol. Res. 2019, 222, 52-59. [CrossRef] [PubMed]

36. Höll, L.; Hilgarth, M.; Geissler, A.J.; Behr, J.; Vogel, R.F. Metatranscriptomic analysis of modified atmosphere packaged poultry meat enables prediction of Brochothrix thermosphacta and Carnobacterium divergens in situ metabolism. Arch. Microbiol. 2020, 202, 1-11. [CrossRef]

37. Nowak, A.; Rygala, A.; Oltuszak-Walczak, E.; Walczak, P. The prevalence and some metabolic traits of Brochothrix thermo-sphacta in meat and meat products packaged in different ways. J. Sci. Food Agric. 2012, 92, 1304-1310. [CrossRef]

38. Domínguez, R.; Pateiro, M.; Gagaoua, M.; Barba, F.J.; Zhang, W.; Lorenzo, J.M. A Comprehensive Review on Lipid Oxidation in Meat and Meat Products. Antioxidants 2019, 8, 429. [CrossRef]

39. Mariutti, L.R.; Bragagnolo, N. Influence of salt on lipid oxidation in meat and seafood products: A review. Food Res. Int. 2017, 94, 90-100. [CrossRef]

40. Cittadini, A.; Domínguez, R.; Gómez, B.; Pateiro, M.; Pérez-Santaescolástica, C.; López-Fernández, O.; Sarriés, M.V.; Lorenzo, J.M. Effect of $\mathrm{NaCl}$ replacement by other chloride salts on physicochemical parameters, proteolysis and lipolysis of dry-cured foal “cecina. " J. Food Sci. Technol. 2020, 57, 1628-1635. [CrossRef] [PubMed]

41. Vidal, V.A.S.; Lorenzo, J.M.; Munekata, P.E.S.; Pollonio, M.A.R. Challenges to reduce or replace $\mathrm{NaCl}$ by chloride salts in meat products made from whole pieces-A review. Crit. Rev. Food Sci. Nutr. 2020, 1-13. [CrossRef]

42. Ao, X.; Kim, I. Effects of grape seed extract on performance, immunity, antioxidant capacity, and meat quality in Pekin ducks. Poult. Sci. 2020, 99, 2078-2086. [CrossRef]

43. Ramírez-Rojo, M.I.; Vargas-Sánchez, R.D.; Torres-Martínez, B.D.M.; Torrescano-Urrutia, G.R.; Lorenzo, J.M.; Sánchez-Escalante, A. Inclusion of Ethanol Extract of Mesquite Leaves to Enhance the Oxidative Stability of Pork Patties. Foods 2019, 8, 631. [CrossRef]

44. Tran, T.T.T.; Ton, N.M.N.; Nguyen, T.T.; Le, V.V.M.; Sajeev, D.; Schilling, M.W.; Dinh, T.T. Application of natural antioxidant extract from guava leaves (Psidium guajava L.) in fresh pork sausage. Meat Sci. 2020, 165, 108106. [CrossRef]

45. Zhang, H.; Liang, Y.; Li, X.; Kang, H. Antioxidant extract from cauliflower leaves effectively improve the stability of pork patties during refrigerated storage. J. Food Process. Preserv. 2020, 44, 14510. [CrossRef] 
46. Nowak, A.; Kalemba, D.; Krala, L.; Piotrowska, M.; Czyżowska, A. The effects of thyme (Thymus vulgaris) and rosemary (Rosmarinus officinalis) essential oils on Brochothrix thermosphacta and on the shelf life of beef packaged in high-oxygen modified atmosphere. Food Microbiol. 2012, 32, 212-216. [CrossRef]

47. Caporaso, J.G.; Kuczynski, J.; Stombaugh, J.; Bittinger, K.; Bushman, F.D.; Costello, E.K.; Fierer, N.; Peña, A.G.; Goodrich, J.K.; Gordon, J.I.; et al. QIIME Allows Analysis of High-Throughput Community Sequencing data. Nat. Methods 2010, 7, 335-336. [CrossRef]

48. Martin, M. Cutadapt removes adapter sequences from high-throughput sequencing reads. EMBnet. J. 2011, 17, 10-12. [CrossRef]

49. Quast, C.; Pruesse, E.; Yilmaz, P.; Gerken, J.; Schweer, T.; Yarza, P.; Peplies, J.; Glöckner, F.O. The SILVA ribosomal RNA gene database project: Improved data processing and web-based tools. Opens external link in new window. Nucl. Acids Res. 2013, 41, D590-D596. [CrossRef]

50. Edgar, R.C. Search and clustering orders of magnitude faster than BLAST. Bioinformatics 2010, 26, 2460-2461. [CrossRef]

51. Tarladgis, B.G.; Watts, B.M.; Younathan, M.T.; Dugan Jr, L. A distillation method for the quantitative determination of malonaldehyde in rancid foods. J. Am. Oil Chem. Soc. 1960, 37, 44-48. [CrossRef]

52. Grau, R.; Hamm, R. Eine einfache methode zur bes-timmung der wasserbindung im fleisch. Fleischwirtschaft $1952,4,295-297$. 